NBER WORKING PAPER SERIES

\title{
CREDIT, PRICES, AND CRASHES: BUSINESS CYCLES WITH A SUDDEN STOP
}

\author{
Enrique G. Mendoza \\ Working Paper 8338 \\ http://www.nber.org/papers/w8338 \\ NATIONAL BUREAU OF ECONOMIC RESEARCH \\ 1050 Massachusetts Avenue \\ Cambridge, MA 02138 \\ June 2001
}

This paper was prepared for the NBER Currency Crises Prevention project headed by Sebastian Edwards and Jeffrey Frankel. Comments by participants at the NBERconference held in Islamorada in January, 2001, particularly those of the discussant Joshua Aizenman, the 2000 Meeting of the Society for Economic Dynamics, and seminars at the Federal Reserve Banks of New York and San Francisco, the IMF, Johns Hopkins University, the University of Michigan, Stanford University, and UC Santa Cruz are gratefully acknowledged. I am also grateful to Katherine Smith (this paper benefitted from discussions on our joint work) and to Fernando Alvarez, Christopher Carroll, Michael Dooley, Rudi Dombusch, Jonathan Heatcote, Urban Jermann, Kent Kimbrough and Carlos Vegh for helpful comments. The views expressed herein are those of the author and not necessarily those of the National Bureau of Economic Research.

(C) 2001 by Enrique G. Mendoza. All rights reserved. Short sections of text, not to exceed two paragraphs, may be quoted without explicit permission provided that full credit, including (C) notice, is given to the source. 
Credit, Prices, and Crashes: Business Cycles with a Sudden Stop

Enrique G. Mendoza

NBER Working Paper No. 8338

June 2001

JEL No. E3, F4, F32, F34

\begin{abstract}
$\underline{\text { ABSTRACT }}$
The 1990s emerging-markets crises were characterized by sudden reversals in inflows of foreign capital followed by unusually large declines in current account deficits, private expenditures, production, and prices of nontradable goods relative to tradables. This paper shows that these Sudden Stops can be the outcome of the equilibrium dynamics of a flexible-price economy with imperfect credit markets. Foreign debt is denominated in units of tradables and a liquidity constraint links credit-market access to the income generated in the nontradables sector and the relative price of nontradables. Sudden Stops occur when real shocks of foreign or domestic origin, or policy-induced shocks make this constraint binding. Sudden Stops are not reflected in long-run business cycle statistics but still they entail nontrivial welfare costs. These results question crises-management policies seeking to impose direct controls on private capital flows and favor those that work to weaken credit frictions.
\end{abstract}

\author{
Enrique G. Mendoza \\ Department of Economics \\ Duke University \\ Durham, NC 27708-0097 \\ and NBER \\ mendozae@econ.duke.edu
}




\section{Introduction}

The epidemic of capital-markets crises that hit emerging economies in the 1990s displayed the empirical regularities of a phenomenon that Calvo (1998) labeled a "Sudden Stop." "Sudden Stops featured a sharp reversal in private capital inflows, or a shift to large outflows, and a corresponding sharp reversal from large current-account deficits into much smaller deficits or small surpluses. These abrupt reversals in foreign financing forced in turn sharp contractions of domestic production and private expenditures, collapses in the real exchange rate, the relative price of nontradable goods in terms of tradable goods, and asset prices, and sharp declines in credit to the private sector. In several cases, Sudden Stops followed from periods during which external deficits widened gradually, the relative price of nontradables and the real exchange rate appreciated sharply, and economic activity and asset prices boomed, often in tandem with explicit or implicit managed exchange-rate regimes.

The features of Sudden Stops resemble those of the balance-of-payments (BOP) crises that developing countries suffer chronically. The literature on contractionary devaluations, for instance, is built on the observation that in developing countries devaluation is generally followed by recession (see Edwards (1986)). Yet, behind this resemblance hide important differences that pose serious challenges both for research and for policy analysis. In particular, as the empirical analysis of Calvo and Reinhart (1999) showed, the changes in real and financial indicators observed in Sudden Stops largely exceeded those of typical BOP crises. Moreover, the economic collapses of Sudden Stops were deep, but the subsequent recoveries were also

\footnotetext{
${ }^{2}$ Rudi Dornbusch noted that the expression originated in comments from an international banker to the paper on Mexico by Dornbusch and Werner (1994), joking that when financing of large current account deficits is compromised "it is not the speed that kills, it is the sudden stop."
} 
generally quick and sharp -- an observation labeled "the Mexican Wave" in a Financial Times editorial by Martin Wolf (August 8, 1999).

The unusual depth of the recessions and price corrections that define Sudden Stops, as well as their short duration, suggests that it may be useful to study this phenomenon within a framework of excess volatility. That is, a framework that can account for Sudden Stops as a short-lived feature of the cyclical dynamics of a small open economy that coexists with the less dramatic stylized facts of the economy's regular business cycle. The aim of this paper is to develop a basic model with these features and to derive its implications for the design of policies to prevent capital-markets crises in emerging economies.

Sudden Stops represent in essence a sudden loss of access to international capital markets, hence it seems clear that explaining Sudden Stops requires researchers to abandon the standard assumption of perfect financial markets typical of equilibrium models of the current account and business cycles in open economies. This paper proposes, in particular, a model in which Sudden Stops are the result of financial frictions at work in an otherwise frictionless, flexible-price competitive environment. Financial frictions drive endogenous credit constraints that are binding or nonbinding on a particular date depending on the state of nature -- although forward-looking behavior on the part economic agents implies that the distortions induced by these constraints are set in motion simply by the expectation that the constraints might bind in the future. Sudden Stops occur in states of nature in which the constraints become endogenously binding, yet the long-run business cycle features of the economy are largely independent of Sudden Stops. In contrast, social welfare can be reduced.

The switch into a Sudden-Stop state can be triggered by large policy shocks (or policycredibility shocks) or by large shocks to domestic productivity or international liquidity (i.e., to 
the world's real interest rate). Thus, "policy uncertainty" and "involuntary contagion," two widely-cited culprits of the recent crises (albeit with different emphasis depending on the country in question) fit the model as explanatory variables of Sudden Stops.

This analysis provides three important policy lessons for crises-prevention strategies. First, regulatory policies implemented with the intent of containing large capital outflows, such as liquidity requirements, margin requirements or value-at-risk collateralization, can be counterproductive because they can increase the likelihood and/or severity of Sudden-Stops. Second, since the paper shows that the resources needed to resolve or prevent a Sudden Stop vary widely depending on the state of the economy at the time credit constraints become binding, financial arrangements that can effectively pre-empt Sudden Stops need to either feature complex state-contingent clauses or commit credibly a large amount of funds. Third, a longterm strategy to deal with Sudden Stops should emphasize policies aimed at addressing directly the informational and institutional frictions that are the ultimate determinants of credit-market imperfections. These include microeconomic policies (such as the development of credit bureaus undertaken recently in Mexico) as well as macroeconomic policies (such as dollarization, the formation of currency unions anchored on strong currencies, or the internationalization of financial systems).

From the standpoint of the growing research program on emerging-markets crises, this paper aims to add to the literature exploring the use of models of credit frictions to study Sudden Stops initiated by Calvo (1998). This literature includes, among others, the works of Aghion, Baccheta and Banerjee (2000), Caballero and Krishnamurty (1999), Cespedes, Chang, and Velasco (2000), Christiano, Gust and Roldos (2000)), Schneider and Tornell (2000), and Paasche (2001). To date, most of this literature has built extensively on modern adaptations of two 
classic approaches to model "great depressions" driven by financial frictions in Macroeconomics: the Keynesian setup of price or wage stickiness with an external financing premium, examined by Bernanke, Gertler and Girlchrist (1998), and the Fisherian analysis of debt-deflations driven by collateral constraints, introduced by Kiyotaki and Moore (1997).

The analysis conducted here differs from existing studies in its approach to model Sudden Stops as an excess volatility phenomenon. Most of the models studied so far in the literature feature credit constraints that are always binding along an equilibrium path. Hence, in this class of models it is difficult to account for the abrupt economic collapses of Sudden Stops as an atypical phenomenon nested within the smoother co-movements of regular business cycles. The model proposed here also differs from the existing literature in that it emphasizes the interaction of uncertainty, risk aversion and incomplete contingent-claims markets in forming the transmission mechanism linking financial frictions to the real economy. In this setting, which is in line with the models studied by Aiyagari (1993), Aiyagari and Gertler (1999), and Eaton and Gersovitz (1981), precautionary saving and state-contingent risk premia play a key role in driving business cycle dynamics. ${ }^{3}$ In contrast, existing models of Sudden Stops based on the Kiyotaki-Moore or Bernanke-Gertler-Girlchrist frameworks assume that borrowers and lenders are risk neutral and are often examined under perfect foresight. These assumptions facilitate the study of the effects of credit frictions by producing models that yield closed-form analytical results and that can be easily solved with linear-approximation algorithms, but leave behind the features of choice under uncertainty, risk aversion and precautionary saving that are often viewed as critical for the analysis of economies with imperfect credit markets. The tradeoff in

\footnotetext{
${ }^{3}$ The model proposed here is also consistent with the predictions of models of the consumption function based on buffer-stock saving and liquidity constraints (see Carroll (2000)).
} 
emphasizing these features is that closed-form solutions are no longer feasible and numerical solutions based on linear approximations are inapplicable. Thus, the predictions of the model have to be derived with the aid of nonlinear numerical solution methods.

The credit constraint examined in this paper is designed with the intent of capturing some of the key elements of the credit frictions identified in the recent literature on emerging-markets crises (see Calvo and Mendoza (2000a)). The proposed credit constraint follows the Fisherian line in that it emphasizes the credit-market effects of price shocks in an otherwise Neoclassical flexible-price environment. In particular, it is shown that Sudden Stops can be consistent with the optimal adjustment of a flexible-price economy in response to a suddenly-binding credit constraint. The constraint takes the form of a liquidity constraint that requires borrowers to finance a fraction of their current obligations out of current income, a criterion widely used to screen borrowers in credit markets.

"Liability dollarization" (i.e., the fact that debt of emerging economies is mostly denominated in U.S. dollars and a few other "strong currencies") is an essential feature of the transmission mechanism by which the liquidity constraint affects the real economy. Since foreign debt is denominated in the international unit of account (i.e., tradable goods), but is leveraged on income valued at a different relative price, sharp fluctuations in the production and relative price of nontradable goods can induce sharp and sudden adjustments in access to foreign financing. These sharp fluctuations in output and prices of nontradables are themselves endogenous outcomes of the model. They represent the equilibrium adjustment of the economy in response to real foreign or domestic shocks or to policy uncertainty. Sudden Stops are possible in this environment even though the model is stripped from the powerful debt-deflation intertemporal channel, and without recurring to the Keynesian assumption that prices or wages 
are inflexible or to the existence of multiple equilibria emphasized in some recent studies (see Calvo (1998), Aghion, Baccheta and Banerjee (2000) and Cespedes, Chang and Velasco (2000)).

The paper is organized as follows. Section 2 summarizes empirical evidence on Sudden Stops and the notion of Sudden Stops as excess macroeconomic volatility. Section 3 sketches the model. Section 4 explores the quantitative implications of the model including its welfare effects. Section 5 describes a variation of the model aimed to account for the asset-pricing features of Sudden Stops. Section 6 concludes.

\section{The Sudden Stops Phenomenon}

Calvo and Reinhart (1999) conducted a comprehensive cross-country analysis of Sudden Stops. They documented 15 recent episodes of large reversals in net private capital inflows into emerging countries. These reversals exceeded 10 percent of GDP in 7 of the 15 cases, and the smallest reversal was equivalent to 4 percent of GDP (Argentina, 1994-1995). The adjustments in real GDP that accompanied these Sudden Stops were also large. Sudden Stops (labeled as “recent experiences" in Tables 8 and 9 of Calvo and Reinhart's paper) produced impact effects on output equivalent to an average decline of 13.3 percent for countries that experienced banking crises, and 12.3 percent for countries that experienced currency crises. These impact effects were much larger than those corresponding to average crises data for the period 1970-1994, which showed declines of 3.2 and 2.7 percent for banking-crisis countries and currency-crisis countries respectively. Calvo and Reinhart also showed that Sudden Stops produced larger adjustments in reserves and real exchange rates, and higher bills for bailing out bankrupt banking systems, than those produced by previous BOP crises. This is particularly the case for the East Asian crisis compared to other regions and to East Asia's recent historical record.

The effects of Sudden Stops on equity prices are well documented in several recent 
reviews of emerging-markets crises by international organizations (see in particular International Monetary Fund (1999)). Although the extent of "true" contagion across equity markets is subject of debate (see Kaminsky and Reinhart (2000) and Forbes and Rigobon (2000)), stock market indexes fell sharply in countries that suffered Sudden Stops. By the end of January 1995, nearly a month after the devaluation of the peso, Mexico's stock market index had fallen by more than 50 percent in dollar terms relative to November 1, 1994. The indexes in Brazil and Argentina fell about 20 percent in the same period. In the East Asian crisis, the collapses of equity prices between September 1 and December 31, 1997 ranged from about 20 percent in Hong Kong to almost 70 percent in South Korea. Equity markets rose from these crash levels but compared to industrial-country markets continued to performed poorly (see Chapter III in International Monetary Fund (1999)). Sudden Stops were also associated with higher asset price volatility. The volatility of weekly emerging-market dollar returns doubled from 2 to 4 percent during the East Asian crisis in 1997 and the Russian collapse in $1998 .{ }^{4}$

The cross-country evidence on the macroeconomic features of Sudden Stops provided by Calvo and Reinhart (1999) is complemented here with time-series evidence that is useful for formalizing the notion of Sudden Stops as an excess volatility phenomenon. The time-series evidence applies to the Sudden Stop experienced in Mexico in the aftermath of the collapse of the peso of December, 1994.

The time-series analysis uses quarterly data for the period 1980:1 to 1997:4 (except for the world real interest rate which covers 1983:1 to 1996:3). Figure 1 plots growth rates of quarterly national accounts data to illustrate the magnitudes of the Sudden Stop in private

\footnotetext{
${ }^{4}$ These figures are means of rolling 13-week standard deviations of equity price indexes in U.S. dollars for 16 emerging markets (see Figure 3.8 in International Monetary Fund (1999)).
} 
domestic absorption, the trade deficit as a share of GDP, and the output of tradables and nontradables. This Figure also shows the period of gradual but sustained expansion and widening trade deficit that preceded the crash, and the relatively rapid recovery after 1995 . Note in addition that, from the perspective of this "raw data" without isolating the business-cycle component, the Sudden Stop in production was larger in the nontradables sector and the recovery in this sector was also more modest than in the tradables sector.

Figure 2 shows the movements in relative prices and exchange rates using monthly data. The picture shows that the severe drop in the real exchange rate at the time of the December, 1994 devaluation reflected, in addition to the nominal devaluation, a collapse in the price of nontradables relative to tradables within Mexico. This occurred after the gradual but substantial increase in that relative price and in the real exchange rate that took place for the duration of the exchange-rate-based stabilization that started in 1988. Mendoza (2001) documents that the sharp real appreciation and increase in the price of nontradables resulted mainly from a major rise in the cost of use of housing. Guerra de Luna (1997) and (1998) show in turn that the high inflation in housing resulted from a large increase in real estate and land prices fueled by the surge in inflows of foreign capital and the expansion in domestic bank credit that preceded the Sudden Stop. Moreover, the Sudden Stop featured important corrections in house and land prices in 1995, coinciding with the large reversal of capital inflows and the collapse of domestic credit. The stylized facts of the Mexican business cycle are computed using the HodrickPrescott (H-P) filter to isolate cyclical components of the data. These stylized facts are listed in Table 1. Mexico's stylized facts display the standard business-cycle pattern for large developing economies (see Mendoza (1995) and Agenor, McDermott and Prasad (2000)). The excess volatility implicit in the Sudden Stop of 1995 can be measured by comparing the depth of the 
observed recession of that year with regular Mexican business cycles in the sample period -defining the latter as deviations from $\mathrm{H}-\mathrm{P}$ trends within two-standard-deviation bands. As Figure 3 shows, the collapses of aggregate GDP, tradables output, nontradables output, consumption, and fixed investment associated with the Sudden Stop in the second quarter of 1995 exceeded the two-standard-deviation limits by margins ranging from 1.5 to 6 percentage points. They are also the only deviations from trend that exceeded those limits during the entire sample period.

\section{Sudden Stops in a Flexible Price Economy with Liquidity Constraints}

This section of the paper proposes a modification of the conventional flexible-price intertemporal approach to current-account determination and business cycles in small open economies that allows for Sudden Stops. The need to modify the conventional approach is obvious in light of its serious empirical shortcomings: models that follow this approach predict smooth movements in foreign debt driven by consumption-smoothing and investmentaugmenting effects that are grossly inconsistent with the sudden reversals of capital inflows and collapses of private consumption observed during a Sudden Stop (see Edwards (2001) and Mendoza (1991a) and (1995)). A key element behind these counterfactual results is the assumption of perfect credit markets: in standard intertemporal models of the current account, agents can borrow or lend at the world-determined real interest rate limited only by the reach of their wealth (as implied by the No-Ponzi-Game condition). Hence, this assumption is relaxed here by considering a credit friction that links the agents' ability to borrow to the endogenous dynamics of prices and income.

Credit frictions are modeled in an exchange economy that abstracts from the existence of money. This leaves behind important real-world features linking credit frictions to the money market, and sets aside an explicit analysis of the role of monetary and exchange-rate policies 
(which has been undertaken in other studies like those of Cespedes et al. (2000) or Mendoza (2001)). ${ }^{5}$ However, it is important to note that the central elements of the credit-channel transmission mechanism envisaged by Fisher (1933) are features of the real credit flows of a non-monetary economy. This is shown by Calvo's (1998) analysis illustrating how Sudden Stops can be the outcome of the real-sector features of frictions in credit markets.

\subsection{Structure of the Model}

Consider a small open economy with an exogenous, stochastic endowment of tradable goods $\exp \left(\mathcal{\varepsilon}_{t}^{T}\right) Y^{T}$, where $\mathcal{\varepsilon}_{t}^{T}$ is a Markovian shock to the mean endowment $Y^{T}$ or to its world value (i.e., the terms of trade). The economy produces nontradable goods using a Cobb-Douglas technology: $Y_{t}{ }^{N}=\exp \left(\varepsilon_{t}{ }^{N}\right) A K^{1-\alpha} L_{t}{ }^{\alpha} . K$ is a time-invariant capital stock with zero depreciation rate, $\varepsilon_{t}{ }^{N}$ is a Markovian productivity shock, and $L$ is labor input. Details on the specification of the Markov processes driving all the shocks present in the model are provided in Section 4.

Firms choose labor demand so as to maximize profits $\pi_{t}$ in units of tradable goods (which are the model's numeraire):

$$
\pi_{t}=\exp \left(\varepsilon_{t}^{T}\right) Y^{T}+p_{t}^{N} \exp \left(\varepsilon_{t}^{N}\right) A K^{1-\alpha} L_{t}^{\alpha}-w_{t} L_{t}
$$

The price of nontradables in units of tradables is $p_{t}^{N}$ and the real wage in units of tradables is $w_{t}$. At equilibrium, firms demand labor up to the point in which the value of the marginal product of labor equals the real wage:

$$
p_{t}^{N} \alpha \exp \left(\varepsilon_{t}{ }^{N}\right) A K^{1-\alpha} L_{t}^{\alpha-1}=w_{t}
$$

Note that since the value of the marginal product of labor depends on $p_{t}^{N}$, a collapse in the

${ }^{5}$ Mendoza (2001) studies the effects of dollarization in a monetary economy with a liquidity requirement similar to the one examined here. 
relative price of nontradables (i.e., a collapse in the real exchange rate since PPP in tradables is assumed to hold) induces a negative shock to labor demand.

Households consume tradable goods $C_{t}^{T}$, nontradable goods $C_{t}^{N}$, and supply labor to firms. They maximize a form of expected utility that incorporates an endogenous rate of time preference (see Epstein (1983)). A standard motivation for preferences of this class in models of the small open economy is that they allow the models to produce well-behaved dynamics and deterministic stationary equilibria in which the rate of time preference equals the world real interest rate. In addition, in the model with credit frictions proposed here, endogenous discounting allows the model to support equilibria in which credit frictions may remain binding in the long run (this point is illustrated later in this section). The utility function is:

$$
U=E_{0}\left[\sum_{t=0}^{\infty} \exp \left\{-\sum_{\tau=0}^{t-1} v\left(C\left(C_{\tau}{ }^{T}, C_{\tau}^{N}\right)-H\left(L_{\tau}\right)\right)\right\} u\left(C\left(C_{t}^{T}, C_{t}^{N}\right)-H\left(L_{t}\right)\right)\right]
$$

In this expression, $U(\cdot)$ is lifetime utility, $C(\cdot)$ is a constant-elasticity-of-substitution (CES) aggregator of consumption of tradables and nontradables, $H(\cdot)$ is a positive, continuously differentiable and concave function that measures the disutility of labor, $u($.$) is an isoelastic$ period utility function, and $v($.$) is the time preference function.$

The specification of the arguments of the $u$ and $v$ functions in terms of the composite good $C-H$ is borrowed from Greenwood, Hercowitz and Huffman, GHH, (1988). In their onegood model, this assumption eliminates the interaction between consumption (or wealth) and labor supply by making the marginal rate of substitution between consumption and labor supply depend only on the latter. This is not the case in the two-sector model of this paper because the relevant real wage for labor supply decisions is measured in units of aggregate consumption, and hence changes in the relative price of nontradables and in the sectoral allocation of consumption 
affect labor supply. Still, the GHH specification simplifies the analysis significantly as illustrated below.

The four functions that characterize lifetime utility adopt the following functional forms:

$$
\begin{gathered}
C\left(C_{t}^{T}, C_{t}^{N}\right)=\left[\omega\left(C_{t}^{T}\right)^{-\eta}+(1-\omega)\left(C_{t}^{N}\right)^{-\eta}\right]^{-\frac{1}{\eta}} \\
H\left(L_{t}\right)=\frac{L_{t}^{\delta}}{\delta}, \quad \delta>0 \\
u\left(C\left(C_{t}^{T}, C_{t}^{N}\right)-H\left(L_{t}\right)\right)=\frac{\left[C\left(C_{t}^{T}, C_{t}^{N}\right)-H\left(L_{t}\right)\right]^{1-\sigma}-1}{1-\sigma} \\
v\left(C\left(C_{t}^{T}, C_{t}^{N}\right)-H\left(L_{t}\right)\right)=\beta\left[\operatorname{Ln}\left(1+C\left(C_{t}^{T}, C_{t}^{N}\right)-H\left(L_{t}\right)\right)\right]
\end{gathered}
$$

These functional forms are standard in real business cycle models of the small open economy (see Mendoza (1991a) and (1995)). The parameter $\eta$ determines the elasticity of substitution between consumption of tradable goods and consumption of nontradable goods, which is given by $1 /(1+\eta), \omega$ is the standard CES weighing factor, $\delta$ determines the elasticity of the supply of labor with respect to the real wage, which is given by $1 /(\delta-1), \sigma$ is the coefficient of constant relative risk aversion (CRRA), and $\beta$ determines the sensitivity of the rate of time preference with respect to changes in the date-t arguments of the period utility function.

Households maximize utility subject to a standard budget constraint:

$$
\begin{aligned}
\left(1+\tau_{t}^{T}\right) C_{t}^{T}+\left(1+\tau_{t}^{N}\right) p_{t}^{N} C_{t}^{N}= & \\
& \pi_{t}+w_{t} L_{t}-b_{t+1}+\exp \left(\varepsilon_{t}^{R}\right) R b_{t}-T_{t}^{T}-p_{t}^{N} T_{t}^{N}
\end{aligned}
$$

Here, $\tau_{t}^{T}$ and $\tau_{t}^{N}$ are consumption taxes that apply to purchases of tradables and nontradables and $T_{t}^{T}$ and $T_{t}^{N}$ are lump-sum taxes levied in units of tradables and nontradables respectively. $b$ represents the economy's net foreign asset position in terms of the only internationally-traded 
asset present in the model: one-period bonds that pay the world-determined gross real interest rate $\exp \left(\mathcal{E}^{R}\right) R$ in units of tradable goods $\left(\mathcal{E}^{R}{ }_{t}\right.$ is a Markovian world interest rate shock, a reasonable proxy for shocks to "international liquidity").

Since the one-period bond is the only asset households exchange with the rest of the world, markets of contingent claims are incomplete and the small open economy's wealth varies with the state of nature. Given the CRRA form of $u(\cdot)$, insurance- market incompleteness implies in turn that consumption responds to fluctuations in the marginal utility of wealth induced by the exogenous shocks, and that households undertake precautionary saving. The latter leads households to effectively impose on themselves an endogenous borrowing constraint even in the absence of explicit credit constraints driven by credit-market imperfections (as in the buffer-stock saving models of Aiyagari (1993) and Carroll (2000)).

The credit-market imperfection present in this model takes the form of a liquidity constraint by which lenders require households to finance a fraction $\varphi$, for $0 \leq \varphi \leq 1$, of their current expenses (i.e., consumption, taxes, and debt payments) out of current income:

$$
w_{t} L_{t}+\pi_{t} \geq \varphi\left[\left(\left(1+\tau_{t}^{T}\right) C_{t}^{T}+\left(1+\tau_{t}^{N}\right) p_{t}^{N} C_{t}^{N}\right)-\exp \left(\varepsilon_{t}^{R}\right) R b_{t}+T_{t}^{T}+p_{t}^{N} T_{t}^{N}\right]
$$

Given the budget constraint, this liquidity requirement is equivalent to a borrowing constraint that limits debt as a share of current income not to exceed $(1-\varphi) / \varphi$ :

$$
b_{t+1} \geq-\frac{1-\varphi}{\varphi}\left[w_{t} L_{t}+\pi_{t}\right]
$$

Note that $\varphi=1$ implies a no-borrowing constraint (i.e., $b_{t+1} \geq 0$ for all $t$ ) and as $\varphi$ converges to 0 the economy approaches the case in which the liquidity constraint is never binding.

Since insurance markets are incomplete, the liquidity constraint gives households an 
extra incentive to engage in precautionary saving, storing away extra assets in the "good" states of nature for the "bad" states in which the constraint may bind and they may not be able to borrow as much as they would desire in world markets. This contrasts sharply with the outcome that would be obtained under perfect foresight. Under perfect foresight (and a constant discount factor) households would hold the largest amount of debt allowed as long as the marginal utility of current consumption exceeds that of future consumption (see also Aiyagari (1993)).

The liquidity requirement is not formally derived as a feature of an optimal credit contract. However, the motivation for it is that it could result from traditional financial-market frictions (such as monitoring costs or bankruptcy risk) or institutional features of credit markets. For instance, Eaton and Gersovitz (1981) show that the probability of default by a risk-averse borrower interacting with a risk-neutral lender in an optimal-contracting framework is increasing in the stock of debt and higher for negative income shocks than for positive income shocks. The liquidity constraint can thus be thought of as a mechanism to (imperfectly) manage default risk by limiting the ability of borrowers to acquire debt and by linking this ability to income realizations. The optimal contract of Eaton and Gersovitz features states of nature in which lending is rationed and an endogenous, equilibrium interest-rate premium that increases with the stock of debt. The liquidity constraint will be shown to yield analogous results in that it produces an endogenous risk premium on the use of foreign debt relative to domestic saving to smooth business-cycle volatility and states of nature in which debt is rationed.

Even if the microfoundations of the liquidity requirement are incomplete, the fact is that the borrowing constraint in equation (10) is consistent with standard lending criteria widely used in mortgage and consumer loans. This is the case even in the financial markets of the industrial world (see the evidence reported by Ludgvison (1996)). In the United States, for instance, the 
$-15-$

large financial companies that anchor the mortgage market (Fannie Mae and Freddie Mac) provide lenders with "scoring" guidelines that effectively require borrowers to keep expected total debt service of prospective borrowers around 1/3 of gross income. ${ }^{6}$ Mortgage debt in the United States as of the second quarter of 2000 was of roughly the same size as the total outstanding corporate debt (about $\$ 4.2$ trillion), and total household debt was 42 percent larger than the total corporate debt. These figures suggest that credit constraints of the form postulated above may be as relevant to consider as the constraints on firm financing emphasized more often in studies of the credit channel.

The liquidity requirement has the additional advantage that it captures in a tractable manner the potentially crippling effects of "liability dollarization" in a flexible-price setting. This is because debt contracts are written in units of tradables but part of the income on which the debt is leveraged originates in the nontradables sector. As a result, a sharp fall in the output of nontradables and/or in the nontradables relative price can trigger a Sudden Stop.

The optimality conditions of the household's problem (listed in Appendix I) have straightforward interpretation. The optimal allocation of consumption across tradable and nontradable goods is determined by equating the atemporal marginal rate of substitution between $C_{t}^{T}$ and $C_{t}^{N}$ with the relative price of nontradables. The optimal supply of labor is set by equating the marginal disutility of labor with the post-tax real wage relevant for household decisions, $w_{t} /\left[p_{t}^{C}\left(1+\tau_{t}^{N}\right)\right]$. Since households care for consumption in terms of the CES aggregator $C$, the

${ }^{6}$ For example, as of October, 2000, Fannie Mae guidelines for conventional mortgages with 20 percent down-payment required that total housing expenses be kept below 33 percent of gross monthly income and total debt payments, including mortgage service, be kept below 38 percent of gross monthly income. Assuming a mortgage rate of 7.5 percent, these guidelines required debt to remain below 35 percent of gross monthly income. 
relevant real wage for them is deflated by $p_{t}{ }^{C}$, which is the relative price of aggregate consumption in units of tradables. Optimal saving is determined by equating the lifetime marginal utility cost of sacrificing a unit of current consumption with the corresponding expected marginal benefit. Marginal lifetime utilities include the impatience effect by which changes to the arguments of period utility at any date $t$ alter the rate at which all future period utilities are discounted. It is also critical to note that, since households desire to consume both tradables and nontradables, the effective return on saving is not just the world real interest rate but the "consumption-based" real interest rate $\exp \left(\mathcal{E}_{t}{ }^{R}\right) R\left[p_{t}{ }^{C}\left(1+\tau_{t}^{T}\right) / p_{t+1}{ }^{C}\left(1+\tau_{t+1}{ }^{T}\right)\right]$. Thus, the intertemporal relative price of consumption in this two-good economy is endogenous despite the small-open-economy assumption and depends on the dynamics of the relative price of nontradables (which is the key determinant of $\left.p^{C}\right)^{7}$

The specification of the model is completed with the description of the government sector. To enable the model to reflect the observed sectoral distribution of government expenditures across tradables and nontradables, it is assumed that the government maintains a constant level of purchases of nontradable goods financed by a constant lump-sum tax. This ensures that the dynamics of the relative price of nontradables reflect only changes in demand and supply by the private sector and not changes in government purchases of nontradables induced by fluctuations in tax revenue. Fluctuations in tax revenue result in fluctuations of government purchases of tradable goods around a given initial amount of lump-sum taxes in units of tradables to be calibrated to the data. This assumption introduces the Calvo-Drazen

${ }^{7}$ Given the CES form of $C, p^{C}$ corresponds to the CES price index obtained from the standard duality problem of minimizing expenditure for a given level of period utility. This implies that $p^{C}$ is an increasing, continuously differentiable function of $p^{N}$. 
fiscal-induced wealth effect that Calvo and Drazen (1988) and Mendoza and Uribe (2001) found critical for explaining key features of economic fluctuations in developing countries exposed to the risk of uncertain duration of government policy. Under these assumptions, the government budget constraint is given by:

$$
G_{t}^{T}+p_{t}^{N} G^{N}=\tau_{t}^{T} C_{t}^{T}+\tau_{t}^{N} C_{t}^{N}+T^{T}+p_{t}^{N} T^{N} \text { with } G^{N}=T^{N}
$$

Tax rates are assumed to be stochastic so as to explore the role of policy uncertainty, or the lack of credibility of existing policies, in triggering Sudden Stops. The model can accommodate differentiated tax rates and degrees of policy uncertainty with regard to tradable and nontradable goods, but for simplicity the analysis that follows considers the case of a uniform tax $\tau_{t}^{T}=\tau_{t}^{N}=\tau_{t}$. This case is interesting to examine because it yields price and wealth distortions on the labor-consumption and saving margins that are nearly equivalent to those produced by the rate of depreciation of the currency in conventional models of exchange-rate management in small open economies (see Mendoza and Uribe (2001) and Mendoza (2001) for details). Thus, a reversal from the low-tax regime to the high-tax regime can be interpreted as a shift from a currency peg to a floating exchange rate regime.

The government announces at date 0 the implementation of a policy reform by which taxes are to be reduced from a high level $\tau^{H}$ to a low level $\tau^{L}$. The policy lacks credibility in the sense that agents assign an exogenous, time-invariant conditional probability to the reversal of the reform $z=\operatorname{Pr}\left[\tau_{t+1}=\tau^{H} \mid \tau_{t}=\tau_{t}^{L}\right]$. The probabilistic process driving the tax rate follows a basic regime-switching specification for discrete-valued random variables governed by an irreducible, ergodic Markov chain. The transition matrix $\Pi$ and the Vector Autoregression representation of the Markov process are: 


$$
\Pi=\left[\begin{array}{cc}
\varsigma & z \\
1-\varsigma & 1-z
\end{array}\right], \quad \zeta_{t+1}=\Pi \zeta_{t}+i_{t+1}
$$

where $\varsigma=\operatorname{Pr}\left[\tau_{t+1}=\tau^{H} \mid \tau_{t}=\tau_{t}^{H}\right], \zeta$ is a $2 \times 1$ random vector such that $\zeta_{t}=(1,0)$ ' when $\tau_{t}=\tau_{t}^{H}$ and $\zeta_{t}=(0,1)$ ' when $\tau_{t}=\tau_{t}^{L}$, and $i_{t+1} \equiv \zeta_{t+1}-E\left(\zeta_{t+1} \mid \zeta_{t} \zeta_{t-1}, \ldots\right)$. The limiting probabilities of the tax regimes are $P\left(\tau_{t}=\tau^{H}\right)=z /(1+z-\varsigma)$ and $P\left(\tau_{t}=\tau^{L}\right)=1-[z /(1+z-\varsigma)]$, and the auto-regressive representation of the process is $\zeta_{j, t+1}=z+(\varsigma-z) \zeta_{j, t}+i_{j, t+1}$ for $j=1,2$. The average duration of the high-tax regime is $1 /(1-\varsigma)$ and that of the low-tax regime is $1 / z$.

\subsection{Competitive Equilibrium and The Business Cycle Transmission Mechanism}

Given an initial foreign asset position $b_{0}$ and the probabilistic processes driving the shocks to productivity, the world's real interest rate, and taxes, a competitive equilibrium for this model economy is defined by state-contingent intertemporal sequences for the allocations $\left[C_{t}^{T}, C_{t}^{N}, C_{t}, L_{t}, b_{t+1}, G_{t}^{T}, Y_{t}^{N}\right]$ and prices $\left[p_{t}^{N}, p_{t}{ }^{C}, w_{t}\right]$ for $t=0, \ldots, \infty$ such that: (a) firms maximize profits subject to their technological constraints, taking $p_{t}^{N}$ and $w_{t}$ as given, (b) households maximize lifetime utility subject to the budget constraint and the liquidity requirement, taking $p_{t}{ }^{N}, p_{t}{ }^{C}$, and $w_{t}$ as given, (c) the government budget constraint holds, and (d) the market-clearing conditions for the markets of tradable and nontradable goods and for the labor market hold.

The competitive equilibrium can be represented by the solution of a modified social planner's problem, which in turn can be solved numerically using dynamic programming methods (see Appendix II for details). This simplification is very useful because of the potentially high degree of non-linearity introduced by the borrowing constraint (see Aiyagari and Gertler (1999)). The model's numerical solution is summarized by two objects. First, a set of state-contingent optimal decision rules for the controls $\left(C_{t}^{T}, C_{t}^{N}, C_{t} L_{t} G_{t}^{T}, Y_{t}^{N}\right)$ and endogenous state $\left(b_{t+1}\right)$ that depend on the current realizations of the states $\left(b_{t} \mathcal{E}_{t}^{T}, \mathcal{E}_{t}^{N}, \mathcal{E}_{t}^{R}, \tau_{t}^{T}, \tau_{t}^{N}\right)$. Second, the 
joint transition and limiting probability distribution functions of these state variables, which jointly with the decision rules determine also the transition and limiting distributions of all of the model's endogenous variables. The equilibrium prices and their corresponding transition and limiting distributions can then be solved for recursively using the optimality conditions of the maximization problems solved by households and firms.

If the liquidity requirement never binds, the model features cyclical dynamics driven by well-known transmission mechanisms. In particular, shocks to productivity and to the world interest rate drive business cycles through the familiar channels examined in real business cycle models of the small open economy (see Mendoza (1991a) and (1995)). Tax shocks induce fluctuations through the wealth and substitution effects highlighted in the studies on the macroeconomic effects of policy uncertainty by Calvo and Drazen (1998) and Mendoza and Uribe (2001). Given a low-tax state at any date $t$, the conditional expected tax rate for $t+1$ is higher than the tax observed at $t$. This triggers an intertemporal substitution effect similar to the one driving perfect-foresight models of non-credible policies based on Calvo (1986): prices are relatively low at $t$ and hence agents substitute consumption intertemporally in favor of current consumption. Under uncertainty and in the presence of non-insurable income effects due to the incompleteness of financial markets, Calvo and Drazen (1998) showed that there is also a statecontingent wealth effect. Each period that low taxes prevail households benefit from the implicit lower level of government absorption, and this gain is added to their permanent income. This effect favors an increasing consumption path for the duration of the low-tax regime followed by a collapse when a reversal of the tax cut takes place.

The above intuition for the real effects of policy uncertainty reflects results that apply fully in partial equilibrium. In general equilibrium, a reversal of a tax cut is likely to induce a 
$-20-$

decline in the output of nontradables, labor allocation, and relative price of nontradables. For the price of nontradables to fall, the reduction in demand for nontradable goods induced by the above-mentioned wealth and intertemporal substitution effects must exceed the reduction in supply. In turn, for the supply of nontradables to fall in equilibrium, it must be the case that the combined effect of the reduction in the demand for labor (resulting from the reduced value of the marginal product of labor in the nontradables sector as $p^{N}$ falls) and the negative effect of the tax hike on labor supply dominates the positive effect on labor supply resulting from the decline in $p^{C}$ (which is caused by the fall in the relative price of nontradables).

The specification of policy uncertainty proposed here differs from that in the CalvoDrazen model in that the high-tax regime is not an absorbent state (i.e., even when the high tax is observed there is still some probability that the low tax can be reinstated), but the basic intuition of the wealth effects that result from market incompleteness remains valid. ${ }^{8}$ The model also differs from the Calvo-Drazen setup in that a reversal to the high-tax state features a "supplyside" effect reducing the supply of labor, as the post-tax real wage falls when the tax rate rises.

The presence of the "occasionally binding" borrowing constraint adds important new elements into the model's business cycle transmission mechanism. In particular, in states of nature in which the credit constraint binds the following effects occur:

(a) The effective real interest rate faced by households increases because the binding borrowing constraint forces them to reduce consumption relative to the case with perfect credit markets. Hence, the collapse in aggregate consumption and in the demand for tradables and nontradables associated with adverse real and/or policy shocks is

${ }^{8}$ The Calvo-Drazen case is the limiting case of the model in which $\varsigma=1$. 
magnified if such a reversal makes the economy run into its borrowing limit.

(b) The effective marginal reward to labor supply rises because the extra unit of labor enhances the household's ability to borrow. This moderates the negative effect of adverse shocks on labor supply.

(c) Consumption, saving, and net foreign asset accumulation (and hence the current account since $b$ is the model's single means of saving) experience intertemporal distortions that depend on the combined dynamic effects of (a) and (b) in general equilibrium. This is because the effective intertemporal relative price of aggregate consumption is determined by the consumption-based real interest rate, which depends on the inverse of the rate of change of the relative price of consumption $\left(p_{t}^{C} / p_{t+1}^{C}\right)$, which in turn depends on the inverse of the rate of change of the relative price of nontradables $\left(p_{t}^{N} / p_{t+1}{ }^{N}\right)$.

As a result of the above effects, households face an implicit risk premium in the use of foreign debt vis-a-vis their own saving in their efforts to smooth consumption that is analogous to the external financing premium faced by firms in models of Sudden Stops based on the Bernanke-Gertler financial accelerator. The differences are in that in the model proposed here the equilibrium risk premium is determined endogenously and is influenced by the risk-averse nature of the households' preferences (which is more in line with the default risk premium in Eaton and Gerosvitz (1981)). In contrast, existing open-economy extensions of the BernankeGertler framework assume that the functional form representing the external financing premium in general equilibrium is identical to the partial-equilibrium solution of a costly-monitoring contracting problem under risk neutrality.

The potential for the liquidity requirement to enlarge output collapses as a result of the effects identified in (a)-(c) can be illustrated more clearly by combining the labor demand and 
supply conditions to derive the following expression for the percent impact effect on the equilibrium allocation of labor that can result from a switch from $\tau_{t}^{L}$ to $\tau_{t}^{H}$ :

$$
\operatorname{Ln}\left(L_{t}{ }^{H}\right)-\operatorname{Ln}\left(L_{t}{ }^{L}\right) \approx \frac{1}{\delta-\alpha}\left\{-\left[\tau_{t}^{H}-\tau_{t}^{L}\right]+\left[\operatorname{Ln}\left(\frac{p_{t}^{N^{H}}}{p_{t}^{C^{H}}}\right)-\operatorname{Ln}\left(\frac{p_{t}^{N^{L}}}{p_{t}^{C^{L}}}\right)\right]+\left[\frac{1-\varphi}{\varphi}\left(\frac{\mu_{t}^{H}}{\lambda_{t}^{H}}-\frac{\mu_{t}^{L}}{\lambda_{t}^{L}}\right)\right]\right\}
$$

where $\mu_{t}$ and $\lambda_{t}$ are the non-negative Lagrange multipliers on the borrowing constraint and the budget constraint respectively and $1 /(\delta$ - $\alpha)$ is always positive because of the parameter restrictions $\delta>1 \geq \alpha \geq 0$. This expression is not a closed-form solution because the relative prices and multipliers in the right-hand side of the expression are endogenous in general equilibrium.

Expression (13) breaks down the impact effect of a tax hike on the equilibrium labor allocation into three effects identified by the three terms in square brackets in the right-hand side. The first effect is the negative effect of the higher tax on labor supply. The second effect is the effect of the change in the price of $C^{N}$ relative to $C$ (i.e., the ratio $p^{N} / p^{C}$ ). This price effect is the combined effect of the change in the price of nontradables on labor demand with that of the change in the price of aggregate consumption on labor supply. Given that $p^{C}$ is the CES price index for the consumption aggregator, it can be shown that $p^{N} / p^{C}$ is increasing in $p^{N}$. Hence, if the price of nontradables falls with the tax hike, $p^{C}$ also falls but the adverse effect of the fall in $p^{N}$ on labor demand dominates the positive effect of the fall in $p^{C}$ on labor supply. ${ }^{9}$ Thus, the decline in the equilibrium allocation of labor in response to a tax hike (and hence in output of nontradables) is magnified on account of this price effect.

${ }^{9}$ Since $p^{N}$ is an increasing function of $C^{T} / C^{N}$, it is possible for $p^{N}$ to increase instead of fall with the tax hike if the collapse in $C^{T}$ is smaller than the collapse in $C^{N}$. The collapse in $C^{\mathrm{T}}$ will tend to be larger because the supply of tradables is more elastic than that of nontradables and because the Calvo-Drazen fiscal induced wealth effect increases government absorption of tradables when the tax increases. 
The third effect operating on the equilibrium allocation of labor is the direct effect of the liquidity constraint and it is only present when the constraint binds. Consider for simplicity a case in which the constraint switches from non-binding to binding with the tax hike (i.e., $\mu_{t}^{L}=0$, $\left.\mu_{t}^{H}>0\right)$. In this case, the constraint makes the fall in equilibrium labor smaller because of the labor-supply incentive provided by the higher effective marginal reward on the extra unit of labor. ${ }^{10}$ However, the binding liquidity constraint also has an indirect effect on equilibrium labor because it distorts relative prices and thus alters the price effect. As shown in Section 4, when a tax hike triggers a Sudden Stop (i.e., when it makes the liquidity constraint suddenly binding), the resulting adjustment in consumption can induce a larger collapse in the price of nontradables than in the case without a Sudden Stop. This indirect effect can dominate the direct effect so that a binding liquidity constraint may enlarge the collapses in labor and nontradables output. Whether $p^{N}$ falls or not will depend on how tight is the credit constraint and how much it reduces tradables consumption relative to nontradables consumption.

The discussion above focuses on the case of tax shocks but similar effects apply to the cases of productivity shocks and shocks to the world interest rate. Hence, Sudden Stops in the model can be driven by policy uncertainty, by domestic productivity shocks, of by foreign shocks affecting the real interest rate, or by a mixture of all three. This is important because of differences attributed to the role of each of these shocks in the particular experiences of countries

${ }^{10}$ This higher reward is given by $[(1-\varphi) / \varphi]\left(\mu_{t}^{H} / \lambda_{t}{ }^{H}\right)$, which depends on the ratio of the two Lagrange multipliers. The latter in turn is determined by intertemporal effects, since the same ratio determines the interest-rate distortion induced by the debt constraint (see Appendix I), and is likely to be nonlinear (if the constraint is marginally binding it might not affect consumption much and thus have a small effect on $\lambda_{t}{ }^{H}$, so $\mu_{t}^{H} / \lambda_{t}{ }^{H}$ increases as the constraint is tightened, but if the constraint is "very tight" it could force a large adjustment in consumption and a large increase in $\lambda_{t}^{H}$ so that $\mu_{t}^{H} / \lambda_{t}^{H}$ may fall as the constraint is tightened). 
that suffered Sudden Stops during the 1990s. Policy uncertainty is widely regarded as an important determinant in the Sudden Stops observed in Latin America, while "exogenous shocks" of foreign or domestic origin are often cited (albeit not without controversy) in accounts of the crises in South East Asia.

The binding credit constraint also has an important connection with the choice to model preferences with an endogenous rate of time preference. In particular, it allows the model to determine endogenously whether a given value of $\varphi$ results in a binding borrowing constraint in the long run for given values of the rest of the model's parameters.

Consider a perfect-foresight variant of the model. In this case, the steady-state consumption Euler equation is:

$$
\left(1+C\left(C^{T}, C^{N}\right)-H(L)\right)^{\beta}=R\left(1-\frac{\mu}{\lambda}\right)^{-1}
$$

where variables without time subscript correspond to steady-state values. The term in the lefthand-side of this expression is the gross rate of time preference. Equation (14), combined with the rest of the steady-state equilibrium conditions, implies that for given parameter values the model features a critical value $\varphi^{\text {crit }}$ below which the borrowing constraint is not binding. Any such $\varphi \leq \varphi^{\text {crit }}$ yields the same steady state, since $\mu=0$ and $R$ is exogenous. The borrowing constraint binds for $\varphi>\varphi^{\text {crit }}$ and the steady-state equilibrium then varies with $\mu / \lambda$, because the latter depends on the tightness of the borrowing constraint relative to the marginal utility of wealth. In this case, the rate of time preference rises to match the higher effective real interest rate in the right-hand-side of (14), thereby supporting the steady state with the binding borrowing limit. Clearly, a standard time-separable utility function with a constant rate of time preference cannot deliver this outcome. For any value of $\varphi$, the liquidity constraint is binding or 
not depending on the exogenous values assigned to the interest rate and the rate of time preference. If they are equal, for example, the constraint never binds at steady state.

\section{A Quantitative Exploration of Business Cycles with a Sudden Stop}

\subsection{Calibration}

The numerical analysis starts from a baseline scenario in which the model's parameters are calibrated so that the deterministic stationary equilibrium of the model mimics several average ratios of macroeconomic aggregates taken from Mexican data. Parameters that cannot be directly related to the data are taken from existing econometric studies or set to values typically used in other studies. The calibration is set to a quarterly frequency, although some ratios of national accounts data are derived from annual figures.

One key aspect of the calibration is setting the values of the parameters that reflect Mexico's ability to access world financial markets. These include both the value of the liquidity coefficient $\varphi$ and the mean net foreign asset position. The deterministic steady-state ratio $b / Y$ is set to -35 percent following the estimates of Mexico's net foreign asset position for the period 1970-1997 provided by Lane and Milesi-Ferretti (1999). This implies that the critical value of the liquidity coefficient is $\varphi^{\text {crit }}=0.741$. Thus, for the borrowing constraint to bind in the deterministic steady state $\varphi$ needs to exceed 0.741 , although lower values of $\varphi$ may still yield a binding borrowing limit in the deterministic transition to steady state or in the stochastic dynamics. The calibration assumes that the borrowing constraint does not bind at steady state (i.e., $\varphi<0.741)$. The stochastic simulations explore the effects of varying $\varphi$ from a low value such that the constraint is never binding within the state space over which the model is solved (which the simulations show to be $\varphi=0.445$ ) to a value $\varphi=0.714$, which limits debt not to exceed 40 percent of income valued at tradable goods prices. 
The model is calibrated to match several average ratios of macroeconomic time series calculated using aggregate and sectoral national accounts data. A consistent time series of Mexico's sectoral national accounts with sufficient detail to compute these ratios is available only for the period 1988 to 1996 or 1998 , depending on the variable. The nontradables (tradables) sector is defined by the industries for which the average ratio of total trade to gross production is less (more) than 0.05 . The industries that belong to the nontradables sector according to this definition are construction, utilities, retailing and commercial services, financial services, and personal, social and community services.

The model is calibrated to match the average aggregate and sectoral GDP, $Y$, shares of consumption, $C$, investment, $I$, and government expenditures, $G$, measured at current prices. Since investment expenditures are not included in the model, they enter in the calibration as constant, lump-sum expenditures in each sector so that the calibration can match the observed GDP shares of consumption (otherwise consumption shares would be too large). Data for the period 1970-1995 yield these average expenditure shares: $C / Y=0.684, I / Y=0.217, G / Y=0.092$. The sectoral data are available for a shorter sample period and the information they provide yields only the average shares of aggregate investment and aggregate government expenditures allocated to tradables $\left(I^{T} / I\right.$ and $\left.G^{T} / G\right)$ and the ratio of tradables GDP to nontradables GDP $\left(Y^{T} / Y^{N}\right)$. The $1988-1998$ average of $Y^{T} / Y^{N}$ is 0.648 . The $1988-1996$ averages of the other expenditure shares are: $I^{T} / I=0.576$ and $G^{T} / G=0.072$.

The above aggregate and sectoral ratios are combined to obtain the following estimates of the shares of sectoral investment and government purchases in each sector's GDP: $I^{T} / Y^{T}=0.32$, 
$G^{T} / Y^{T}=0.017, I^{N} / Y^{N}=0.151$, and $G^{N} / Y^{N}=0.141{ }^{11}$ Estimates of sectoral consumption-output ratios are then derived using the expenditures definition of GDP and the average net exports-GDP ratio for 1970-1995, $N X / Y=-0.001$. The consumption-GDP ratios are $C^{T} / Y^{T}=0.665$ and $C^{N} / Y^{N}=0.708$.

The calibration is normalized by setting $Y^{T}=1, K=1$, and $p^{N}=1$. The average sectoral share of labor income in the nontradables sector for the 1988-1996 period yields $\alpha N=0.364$. The elasticity of substitution between $C^{T}$ and $C^{N}, 1 /(1+\eta)$, is set to the value estimated by Ostry and Reinhart (1992). Their estimate of $\eta$ for developing countries is $\eta=0.316$. Estimates of the wage elasticity of labor supply in Mexico's nontradables sector are not available, so the calibration assumes unitary-elasticity as a benchmark, this implies $\delta=2$. The uniform consumption tax rate is set to $\tau=0.079$ which is the mean tax rate that results from the regime-switching Markov process specified below. $R$ is set to the quarterly equivalent of a gross real interest rate of 1.065 per year and $\sigma$ is set to 2, both standard values in Real Business Cycle theory.

The calibration values for $A, \omega, \beta, T^{T}$ and $T^{N}$ and the corresponding steady-state levels of $C^{T}, C^{N}, L, Y^{N}$ and $b$ are jointly determined by solving the non-linear simultaneous equation system conformed by the steady-state equilibrium conditions of the model, imposing the calibration ratios and parameters described in the previous paragraphs and summarized in Table 2. The solution implies $A=1.958, \omega=0.342, \beta=0.027, T^{T}=-0.139$, and $T^{N}=0.119$. Note that the value of $\beta$ implies a small semi-elasticity of the rate of time preference to changes in consumption and labor supply, which makes impatience effects of second-order importance.

The remaining parameters that need to be set are those pertaining to the stochastic processes of tax-rate, productivity, and interest-rate shocks. The process for the uniform tax rate

\footnotetext{
${ }^{11}$ For example, given $I / Y, I^{T} / I$ and $Y^{T} / Y^{N}, I^{T} / Y^{T}$ is given by $(I / Y)\left(I^{T} / I\right)\left[1+\left(Y^{T} / Y^{N}\right)\right]$.
} 
$-28-$

is set to mimic the price distortions on saving and labor supply induced by sudden devaluations of the currency in a monetary variant of the model calibrated to Mexico (see Mendoza (2001) for details). The low-tax state (set to match a permanently fixed exchange rate) is 2.1 percent and the high-tax state (set to match an annual rate of depreciation of the currency of 50 percent) is 11.8 percent. The mean duration of the low-tax regime is 24 quarters (6 years), which matches the observed durations of Mexico's managed exchange rate regimes of 1970-1976, 1976-1982 and 1988-1994. The mean duration of the high-tax regime is set to 36 quarters (9 years) so as to yield a probability of staying in the high-tax regime higher than that of staying in the low-tax regime (which approximates the standard assumption of the literature on policy temporariness that treats the "bad policy" state as absorbent). The mean durations of the tax regimes imply that the probability of switching from the low tax to the high tax $(z)$ is 4.2 percent per quarter and the probability of continuation of the high tax state $(\varsigma)$ is 97.2 percent. The mean tax is 7.93 percent, with a standard deviation of 0.047 and a coefficient of first-order autocorrelation equal to 0.93 .

The stochastic processes driving productivity shocks and world-interest-rate shocks are represented by standard two-state, symmetric Markov processes that satisfy the "simple persistence" rule following the same method applied in Mendoza (1995). These processes are statistically independent of the one driving the tax rates. For simplicity, the simulations assume common productivity shocks across sectors (i.e., $\mathcal{E}_{t}^{N}=\mathcal{E}_{t}^{T}=\mathcal{E}_{t}$ ). Since tradables output is an endowment equal to one unit of tradable goods, the standard deviation of productivity shocks is set to mimic the standard deviation of tradables GDP in Mexico (3.36 percent). The standard deviation of shocks to the world real interest rate is set to 0.881 percent, which is the standard deviation of the H-P filtered measure of the gross world real interest rate proposed by Agenor et al. (2000). The correlation coefficient between the two shocks matches the sample correlation of 
$-29-$

Mexico's tradables GDP with the world's real interest rate (-0.116). Symmetry and "simple persistence" imply that the shocks share a common first-order serial autocorrelation coefficient which is set to match the first-order serial autocorrelation of Mexican tradables GDP, 0.553 -the autocorrelation of the world real interest rate is slightly higher at 0.771 .

\subsection{Numerical Solutions: How Large and Costly are Business Cycles with Sudden Stops?}

The model is solved by value-function iteration over a discretized state space. The state space consists of the combinations of the two possible realizations of each of the three shocks, $\mathcal{E}$ $=\{0.0336,-0.0336\}, \mathcal{E}^{R}=\{0.0088,-0.0088\}, \tau=\{0.118,0.021\}$ and the 1200 values in an evenlyspaced grid of net foreign asset positions spanning the interval $[-2.788,2.608]$. Thus, there are 8 combinations of the triple $\left(\mathcal{E}, \mathcal{E}^{R}, \tau\right)$ that describe the possible realizations of exogenous shocks at each date, and a total of $1200 \times 8=9600$ coordinates in the state space.

Figure 4 plots the limiting probability distribution functions (PDF) of net foreign assets in the economies with perfect credit markets and with the liquidity constraint. The mean net foreign asset position of the economy with perfect credit markets is -0.097 , which implies an average $b / Y$ ratio of -4.5 percent. This amount of foreign debt is only 10.9 percent of that held in the deterministic steady state, which illustrates the large amount of precautionary saving that households undertake given the economy's uncertainty and the incompleteness of financial markets (even when the credit market functions perfectly).

Adding the extra incentive for precautionary saving due to the liquidity constraint shifts the economy to a positive value for mean holdings of foreign assets of 0.258 (an average $b / Y$ ratio of 9.3 percent). The economy with the liquidity constraint also differs in that there is a mass of probability (equal to 0.38 percent) concentrated at a threshold net foreign asset position, or maximum debt position, in which the constraint switches from binding in at least some states 
to nonbinding in all states of nature. ${ }^{12}$ Thus, even though the credit constraint is modeled in terms of the ratio of debt to current income, optimal "debt management" by liquidity-constrained agents yields a stochastic steady state in which the level of the stock of foreign debt never exceeds an endogenous maximum. This level corresponds to the maximum stationary debt position that can be supported with the credit constraint marginally nonbinding under the "worst-case-scenario" in which productivity is low, the world real interest is high, and the consumption tax is high. Hence, the liquidity constraint is an effective means to induce creditmarket outcomes in which debt is "rationed" and as a result incentives to default are weakened, albeit only in the long-run. In the short run, the distribution of foreign assets adjusts gradually to reach the limiting distribution, and there are positive-probability states of nature in which debt is high and the economy is exposed to Sudden Stops depending on the realizations of real and policy-induced shocks.

Table 3 lists the business cycle co-movements that correspond to the limiting distributions of the economies with and without liquidity constraints. Both model economies yield standard deviations (relative to the standard deviation of nontradables GDP) and first-order autocorrelations for aggregate consumption and the relative price of nontradables that mimic closely those observed in the data (see Table 1). The variability of total output and sectoral outputs is somewhat smaller in the models than in the data.

The liquidity constraint has a clear effect on the first and second moments of net foreign assets and net exports, but the rest of the moments listed in Table 3 vary slightly. The mean of

${ }^{12}$ These features of the limiting distributions of assets in economies with precautionary saving with and without liquidity constraints are qualitatively identical to those obtained in the recent literature on the consumption function in partial equilibrium (see Carroll (2000)). 
net foreign assets increases and their variability diminishes when the liquidity constraint is present. Clearly, except for these changes in the moments of external variables, the possibility of Sudden Stops that results from the liquidity constraint has a negligible effect on the long-run business cycle co-movements of the economy.

Figure 5 plots the impact effects of a switch from the "best" state with regard to exogenous shocks (i.e., $\mathcal{E}=0.0336, \mathcal{E}^{R}=-0.0088, \tau=0.021$ ) to the "worst" state (i.e., $\mathcal{E}=-0.0336$, $\mathcal{E}^{R}=-0.0088, \tau=0.118$ ) as a function of the first 600 coordinates in the foreign-asset grid. Impact effects are reported again for the cases with and without liquidity constraint. These impact effects can be classified into three distinct ranges. First, for a range of sufficiently high foreignasset positions (i.e., low debt) the constraint does not bind and the impact effects are the same in the two economies. A switch to the "worst" state increases the debt-GDP ratio and widens the current account deficit as a share of GDP. GDP at tradable goods prices, consumption, consumption of tradables, labor, the price of nontradables, and output of nontradables all fall sharply (the declines range between 10 and 20 percent relative to the level in the "best" state). These effects are in line with the wealth and substitution effects described in Section 3 for the economy without credit constraints. Note also that in the economy without liquidity constraints the magnitude of the effects is roughly the same for any foreign asset position (except that the decline in $b_{t+1} / Y_{t}$ is larger the lower is $\left.b_{t}\right)$. Thus, the economy without liquidity constraints cannot explain Sudden Stops, even though it features precautionary saving and its long-run business cycle moments are similar to those of the economy with liquidity constraints.

The second relevant range of impact effects corresponds to values of $b_{t}$ lower than the 364th coordinate in the foreign asset grid. In this range, the liquidity constraint is binding regardless of the realizations of the shocks, and hence $b_{t+1} / Y_{t}$ cannot change across states of 
nature. Still, the constraint is not equally binding in each state so the other impact effects in Figure 5 vary. In particular, for this range of foreign asset positions, the declines in $Y_{t}, C_{t}, C_{t}^{T}$, $L_{t}, p_{t}^{N}$ and $Y_{t}^{N}$ are smaller the higher the stock of initial debt (i.e., the lower $b_{t}$ ). For foreign asset positions lower than coordinate 100 in the grid, it is even possible to obtain declines in labor supply and nontradables GDP smaller than those obtained in the absence of the credit constraint, as the effect of the higher marginal reward on labor supply outweighs all of the other supply and demand effects described earlier. However, this range of foreign asset positions is of little interest because it has a negligible steady-state probability of being observed (see Figure 4), and in the economy with credit constraints they represent states from which the economy departs very quickly and has zero probability of returning to. The latter can be observed in Figure 6 which plots the transitional dynamics of the PDF of foreign assets in the liquidity-constrained economy starting from the lowest value of $b$. There is zero probability of observing values of $b$ lower than the $200^{\text {th }}$ coordinate after just two quarters.

The third range of impact effects is particularly important because it corresponds to cases in which the credit constraint is not binding in some states of nature but shifts to become binding in others. In Figure 5, the constraint shifts from nonbinding to binding as the economy switches from the "best" to the "worst" state for values of $b_{t}$ between the $364^{\text {th }}$ and $417^{\text {th }}$ coordinates in the foreign asset grid. There is still room for adjustment in the $b / Y$ ratio because the constraint is not binding in the "best" state, but the adjustment is smaller than in the economy with perfect credit markets. At the high end of this range, the model yields Sudden Stop dynamics with a large reversal in the current account deficit and collapses in $Y_{t}, C_{t}, C_{t}^{T}, L_{t}, p_{t}^{N}$ and $Y_{t}^{N}$ larger than those of the economy with perfect credit markets. These larger collapses follow from the intuition developed to explain the impact effect of a tax hike on labor supply in Section 3 using equation 
(13). However, note that in the Figure the shift is not only from low to high tax but also from high productivity and low world real interest rate to the opposite. This explains why in part of the Sudden Stop range it is possible for labor and nontradables output to fall sharply even in states in which the price of nontradables is actually rising sharply.

Sudden Stops are dramatic events but they are also relatively rare. The range of foreign asset positions that supports Sudden Stops is nearly ruled out of the limiting PDF of foreign assets in the credit-constrained economy by the households' precautionary saving. The only relevant coordinate is the maximum debt point identified earlier in which the economy is on the threshold of moving into states in which the constraint is not binding regardless of the realizations of the shocks. However, in contrast with the high-debt states from which the economy moves away nearly instantaneously, Figure 6 shows that even after 4 to 6 quarters of transitional dynamics (starting from a high-debt state) the economy is still in a range in which Sudden Stops are very likely. Thus, on account of both the skewness of the steady-state distribution of foreign assets around the Sudden Stop threshold and the high probability of transiting through states in which Sudden Stops are very likely off the steady state, one can conjecture that small unexpected real shocks or disturbances to market access can be a powerful trigger of Sudden Stops.

What is the welfare cost of the credit constraint that drives Sudden Stops? Figure 7 plots welfare costs measured as percent compensating variations in consumption across time and states of nature that equalize the lifetime utilities of the economies with and without the constraint. The chart plots the costs at the "best" and "worst" realizations of the exogenous shocks and the conditional mean cost across shocks for given values of $b_{t}$. These welfare costs follow a similar pattern as the impact effects of Figure 5. In the low-debt (high $\left.b_{t}\right)$ range in 
which the liquidity constraint is not binding for any realization of the shocks there is virtually no welfare loss. Welfare costs rise as the initial foreign asset position falls into the Sudden Stop range. The largest loss in this range reaches about 0.6 percent. Finally, in the high-debt (low $b_{t}$ ) range in which the constraint binds regardless of the state of nature, welfare costs rise rapidly as $b_{t}$ falls. The cost reaches 16 percent at the lowest $b_{t}$ and the "worst" state of nature.

The information contained in the state-contingent welfare losses of Figure 7 can be aggregated by computing the unconditional mean of welfare costs using the limiting PDF of the economy with perfect credit markets. The mean welfare cost equals 0.3 percent. A comparison of Figures 4 and 7 shows that this estimate reflects mainly welfare losses in the Sudden Stop range. A cost of 0.3 percent is large when compared to existing results showing that the cost of giving up foreign asset trading to offset business-cycle risk is negligible (see Mendoza (1991b) and Cole and Obstfeld (1991)). Mendoza (1991b) estimated the cost at 0.02 percent using a small open economy model with incomplete insurance markets but perfect credit markets calibrated to Canada. ${ }^{13}$ The mean welfare cost of the liquidity constraint is 15 times larger. ${ }^{14}$

The welfare costs of Sudden Stops plotted in Figure 7 have an interesting policy interpretation as measures of the welfare costs associated with an unexpected structural shock that permanently increases $\varphi$ from $\varphi \leq 0.445$ to $\varphi=0.714$ (the values that support the

${ }^{13}$ The model in Mendoza (1991b) includes investment, which gives households a vehicle for precautionary saving even when the economy moves into international financial autarky. The two exercises would not be comparable otherwise because in the absence of investment households in that model would have to consume their random endowments each period.

${ }^{14} \mathrm{~A}$ key determinant of the mean welfare cost is the position of the "maximum debt" in the PDF of foreign assets of the credit-constrained economy relative to the mean foreign asset position with perfect credit markets. In the simulations conducted here, that maximum debt is lower than the mean $b$ of the unconstrained economy. Mendoza (2001) finds a much larger expected welfare cost of 4.6 percent when the opposite occurs. 
unconstrained and constrained limiting PDFs in Figure 4). This shock can be interpreted as a permanent exogenous shock to world credit-market access or as a domestic policy action aimed at avoiding balance-of-payments crises by limiting the ability of the private sector to contract foreign debt (i.e., by introducing capital controls). The intuition under both interpretations is that before the permanent, unanticipated shock to $\varphi$, the long-run probability of observing a particular debt position was determined by the PDF of the economy with perfect credit markets. From each of these possible initial conditions, the economy suffers the welfare losses plotted in Figure 7 as a result of the permanent shock to the ability to borrow. These losses capture the entire transitional dynamics to the new stochastic steady state of the credit-constrained economy. The average loss at 0.3 percent is not excessive, but the losses associated with high-debt scenarios that reach up to 16 percent with positive probability are staggering. The permanent shock to the ability to borrow sets these "vulnerable" high-debt economies on an adjustment path in which Sudden Stops are very likely to occur, as the transitional distributions in Figure 6 show, even though Sudden Stops are very rare in the long run.

The above results suggest two important lessons. First, well-intentioned policies aimed at preventing Sudden Stops by introducing capital controls are counter-productive. They increase the probability of Sudden Stops in the short run and can entail substantial welfare costs. Second, persistent changes on the "credit-worthiness" of emerging economies have the perverse effect that they also lead to an increased short-run probability of Sudden Stops. Foreign creditors may try to manage default risk by increasing $\varphi$ but in doing so they also increase the probability of Sudden-Stop-like crises that might have first motivated the increase in $\varphi$.

The liquidity constraint also has interesting implications for the welfare cost of business cycles. The cost of business cycles is measured by the compensating variation in consumption 
across time and states of nature that equalizes the expected lifetime utility of the stochastic model and the deterministic lifetime utility of the same model under perfect foresight (with the shocks set at their mean values). It is well-known from the analysis in Lucas (1987) that the cost of business cycles is very small in models with CRRA utility and trend-stationary consumption for any reasonable values of the standard deviation of consumption and the coefficient of relative risk aversion -- Lucas's estimates for the U.S. economy range between 0.008 and 0.04 percent for risk aversion coefficients between 1 and 5.

In the model examined here, the mean welfare cost of business cycles is also very small with or without the liquidity constraint. However, business cycles can be significantly more costly for the liquidity-constrained economy. Mean welfare costs of business cycles conditional on the foreign asset position are plotted in Figure 8. The cost of business cycles is uniformly higher for the liquidity-constrained economy, by as much as 0.5 percent, than for the economy with perfect credit markets in the range of foreign asset positions near the maximum allowable debt (between coordinates 413 and 595 in the foreign asset grid). The costs are approximately the same for higher foreign asset positions. ${ }^{15}$ Relative to the mean welfare cost of business cycles in the economy with perfect credit markets conditional on values of $b$ higher than the maximum debt of the debt-constrained economy, the mean cost of business cycles under a liquidity constraint exceeds the cost under perfect credit markets by 0.03 percentage points.

\footnotetext{
${ }^{15}$ Note that for high values of $b_{t}$ in Figure 8 the welfare cost can be negative (i.e., eliminating all shocks to productivity, the interest rate and taxes can reduce welfare). This deviates from the standard result in models like Lucas's because in the incomplete-markets, precautionary-saving model examined here the elimination of uncertainty has implications for wealth and relative prices. In particular, doing away with tax policy uncertainty eliminates the Calvo-Drazen fiscal-induced wealth effect. If the exercise is repeated without considering tax shocks, the cost of business cycles is small but always positive.
} 
The mean cost of business cycles remains small in as much as the model retains features similar to those behind Lucas's calculations. It is well-known that deviations from his setup can result in much larger estimates of welfare costs of business cycles. For example, if businesscycle risk affects long-run growth (see Aizenman and Marion (1993), Ramey and Ramey (1995), and Mendoza (1997)), the cost of business cycles can be very large. The aim of the comparison of costs of business cycles conducted here, however, is simply to show that the cost is higher with credit frictions than without them within a standard business cycle framework. ${ }^{16}$

\subsection{Sensitivity Analysis: Risk Aversion and Sources of Shocks}

The analysis of the dynamics of the model under a liquidity constraint suggests that the quantitative results should depend critically on the coefficient of relative risk aversion, which drives the desire to undertake precautionary saving. The sensitivity of the results to changes in this parameters is examined next. In addition, since some emerging economies that suffered Sudden Stops are believed to have been less susceptible to policy uncertainty than Mexico, it is worth examining whether the mode can generate Sudden Stops only as a result of exogenous shocks to productivity and/or the world real interest rate.

An increase in the coefficient of relative risk aversion $\sigma$ from 2 to 5 increases significantly the incentive to undertake precautionary saving for both the economy with perfect credit markets and the economy with liquidity constraints. In the economy with perfect credit markets, the mean net foreign asset position increases to 1.35 , compared to -0.097 when $\sigma=2$ (the mean debt-output ratio rises to 0.43 compared to -0.045). The features of business cycles across

\footnotetext{
${ }^{16}$ Since precautionary saving is one of the mechanisms that drives the linkage between volatility and growth, and the same mechanism drives the dynamics of the credit-constrained economy, it is likely that welfare costs of business cycles will remain higher with credit constraints than without them even in the presence of a linkage between volatility and growth.
} 
$-38-$

economies with $\sigma=2$ and $\sigma=5$ differ. In particular, the standard deviations of $C^{T}$ and $P^{N}$ increase by 0.75 and 3 percentage points respectively, and those of $L, Y^{N}, C^{N}$ and $C$ fall by 0.5 to 0.75 percentage points. However, it is still the case that with $\sigma=5$ business cycles do not differ much across economies with and without liquidity constraints. Examining the impact effects of a switch from the "best" to the "worst" state, it also remains the case that the economy with perfect credit markets does not display Sudden Stops, while the economy with the liquidity constraint features a region of foreign asset positions in which Sudden Stops occur. The features of these Sudden Stops are qualitatively similar to the ones obtained with $\sigma=2$, except that with the higher value of $\sigma$ the impact effect on the price of nontradables is always positive (both with and without the liquidity constraint). In general, the result that the model with the liquidity constraint displays Sudden Stops while showing similar long-run business cycle co-movements as the economy with perfect credit markets is robust to the increase in $\sigma$.

The higher value of $\sigma$ has important implications for the transitional dynamics of the probability distribution of the model's state variables. In particular, as a comparison of Figures 6 and 9 shows, the distribution (starting from the largest debt position in the state space) converges to the limiting distribution at a much slower pace. While with $\sigma=2$ the distribution is out of the Sudden-Stop range after 6 quarters, in the case with $\sigma=5$ the distribution assigns a significant probability mass to debt positions in which Sudden Stops can occur even after 50 quarters. Similarly, the increased degree of risk aversion results in higher welfare costs induced by the liquidity constraint and in relatively higher welfare costs of business cycles with liquidity constraints than with perfect credit markets. The expected welfare cost of the credit constraint increases sharply to 22.8 percent. The mean cost of business cycles is 3.8 times larger with the liquidity constraint than with perfect credit markets, although the costs of business cycles are 
still small in both cases (the costs are 0.074 percent with liquidity constraints and 0.019 percent with perfect credit markets).

The sensitivity analysis for the case in which the economy does not face tax policy uncertainty shows important differences in business cycle properties relative to the baseline economy with tax shocks. In particular, there is a marked fall in the cyclical variability of all macroeconomic aggregates and in their correlations with output. However, comparing across economies without tax shocks, business cycle regularities continue to be roughly the same with and without liquidity constraints.

Sudden Stops also continue to be a feature of the impact effects of the liquidityconstrained economy in response to a switch from a high-productivity, low-interest-rate state to a low-productivity, high-interest-rate state when initial debt is sufficiently large. The collapses in labor and aggregate consumption are smaller than in the presence of tax shocks. Without tax shocks the largest collapses are equal to 35 and 23 percent for labor and consumption respectively, compared to 70 and 45 percent in the economy with tax shocks. Declines in the price of nontradables are harder to account for without tax shocks, but this is true with or without the liquidity constraint - in both cases the impact effect of a switch from the best to worst states is an increase in the price of nontradables. It is still the case, however, that for the region of the largest Sudden Stops in output and consumption the level of the price of nontradables rises by less than in the economy with perfect credit markets. Thus, the key finding that liquidity constraints can result in short-lived Sudden Stops that are hard to notice in long-run business cycle co-movements is robust to the elimination of tax shocks. Sudden Stops can be a feature of the dynamics of economies in which policy uncertainty is not an issue.

The absence of policy uncertainty does alter significantly the welfare implications of the 
model. Welfare costs of the liquidity constraint are smaller in the economy without tax shocks, as would be expected given the smaller magnitude of the Sudden Stops in this case. The expected welfare cost of the liquidity constraint falls from 0.3 percent with tax shocks to 0.1 percent without tax shocks. With regard to the effect of the liquidity constraint on the cost of business cycles, the cost of business cycles without tax shocks is roughly the same in the economy with perfect credit markets and in the economy with liquidity constraints (at about 0.14 percent). ${ }^{17}$ Hence, in the absence of tax shocks the liquidity constraint has smaller welfare costs and does not increase the cost of business cycles. These results are more in line with Mendoza's (1991b) findings showing small costs of forcing small open economies facing productivity shocks into international financial autarky.

\section{Equity Prices, Margin Requirements, and Excess Volatility of Portfolio Flows}

The framework developed in Section 3 is modified here to propose a model in which a credit-market imperfection may induce large shifts in portfolio flows and equity prices. The model is based on a variation of a closed-economy model proposed by Aiyagari and Gertler (1999). The model considers agents in the domestic small open economy that trade shares of their capital stock with foreign securities firms while being subject to margin requirements. Foreign firms specialize in holding equity of the small open economy and face portfolio adjustment costs that result from their disadvantaged position in trading equity relative to residents of that economy in terms of information or institutional features. Frankel and

\footnotetext{
${ }^{17}$ Interestingly, the mean cost of business cycles in these cases is higher than in the economy with tax shocks, in which the mean cost was less than 0.01 percent. This is because of the Calvo-Drazen fiscal-induced wealth effect triggered by tax shocks. Low-tax states increase wealth because of the implied reduction in unproductive government expenditures. Mendoza and Uribe (2001) showed that policy uncertainty can be welfare-improving in this case.
} 
Schmukler (1996) provide empirical evidence suggesting that indeed foreign traders are at a disadvantage relative to traders in domestic equity markets of emerging economies.

The model is simplified to consider only a single, homogeneous tradable good. This offers two important advantages in setting up the asset pricing model. First, it implies that the GHH specification of the argument of utility eliminates the wealth effect on labor supply and isolates completely the labor supply decision from the dynamics of consumption, saving and portfolio choices. Second, since the optimal labor demand and profits of firms are unaffected by credit frictions, the model features a supply-side that corresponds exactly to that of a frictionless economy. As a result of these two features, equilibrium dividend streams and labor-market allocations are independent of saving decisions and credit frictions. The tradeoff is that in this setting a Sudden Stop does not induce an unusually large output collapse, even though it still causes excessive current account reversals and collapses of private consumption.

Production is undertaken with the same Cobb-Douglas technology as before: $Y_{t}=$ $\exp \left(\mathcal{E}_{t}\right) A K^{1-\alpha} L_{t}{ }^{\alpha}$. Profit-maximizing firms choose labor demand so that at each date $t$ labor demand is given by the standard productivity condition:

$$
\exp \left(\varepsilon_{t}\right) A \alpha K^{1-\alpha} L_{t}^{\alpha-1}=w_{t}
$$

Dividend payments are given by:

$$
d_{t}=\exp \left(\varepsilon_{t}\right) A(1-\alpha) K^{-\alpha} L_{t}^{\alpha}
$$

Expected lifetime utility is the same as before (except that $C$ is now made of a single consumption good). Households maximize utility subject to the following budget constraint:

$$
\left(1+\tau_{t}\right) C_{t}=a_{t} K d_{t}+w_{t} L_{t}+q_{t}\left(a_{t}-a_{t+1}\right) K-b_{t+1}+b_{t} \exp \left(\varepsilon_{t}^{R}\right) R
$$

where $\tau_{t}$ is a random consumption tax (which can also be interpreted as an import tariff), $a_{t}$ and 
$a_{t+1}$ are beginning- and end-of-period shares of the domestic capital stock owned by domestic households, $d_{t}$ are dividends paid by domestic firms and $q_{t}$ is the price of equity. Households also face a margin requirement according to which they must finance a fraction $\kappa$ of their equity holdings out of current saving:

$$
a_{t} K d_{t}+w_{t} L_{t}+q_{t} a_{t} K+b_{t} \exp \left(\varepsilon_{t}^{R}\right) R-\left(1+\tau_{t}\right) C_{t} \geq \kappa q_{t} a_{t+1} K
$$

Given the budget constraint, the margin requirement imposes a "collateral" constraint on foreign borrowing of the form:

$$
b_{t+1} \geq-(1-\kappa) q_{t} a_{t+1} K
$$

This constraint differs sharply from the liquidity requirement because it depends on the price of equity, which is a forward-looking variable. Note that the constraint can also be interpreted as restricting the stock of savings (i.e., $q_{t} a_{t+1} K+b_{t+1}$ ) to be larger than $\kappa q_{t} a_{t+1} K$.

The optimality conditions of the households' problem have similar features as before, except that a binding borrowing constraint does not distort labor supply and cannot induce distortions via the dynamics of relative goods prices. A binding borrowing constraint still increases the expected effective real interest rate of the small open economy relative to the world real interest rate. Furthermore, if the expected return on equity is defined as $E_{t}\left[R_{t+1}^{q}\right] \equiv E_{t}\left[\left(d_{t+1}+q_{t+1}\right) / q_{t}\right]$, the optimality conditions on debt and equity yield the following expression for the equity premium:

$$
E_{t}\left[R_{t+1}^{q}\right]-E_{t}\left[\exp \left(\varepsilon_{t+1}^{R}\right)\right] R=\frac{\eta_{t} \kappa-\operatorname{COV}\left(\lambda_{t+1}, R_{t+1}^{q}\right)+\operatorname{COV}\left(\lambda_{t+1}, \exp \left(\varepsilon_{t+1}^{R}\right) R\right)}{E_{t}\left[\lambda_{t+1}\right]}
$$

where $\lambda$ and $\eta$ are the non-negative Lagrange multipliers on the budget constraint and the margin constraint respectively. 
If the world real interest rate is deterministic, the last covariance term in the numerator of the right-hand-side of (20) vanishes. In this case, and if the margin requirement never binds (i.e., $\eta_{t}=0$ for all $t$ ), the formula yields the standard equity-premium formula under perfect credit markets. In contrast, a binding margin requirement at date $t$ (i.e., $\eta_{t}>0$ ) causes an excess equity premium because the pressure that the margin call exerts on households to fire-sell equity depresses the current equity price. The effect of the binding margin constraint at $t$ is likely to be persistent because, as shown below, foreign traders adjust their portfolios slowly.

Using the standard forward-solution method, it follows that optimal portfolio decisions by agents in the small open economy require the equity price to satisfy:

$$
q_{t}=E_{t}\left(\sum_{i=0}^{\infty}\left[\prod_{j=0}^{i} \frac{\lambda_{t+1+j}}{\lambda_{t+j}-\eta_{t+j}(1-\kappa)}\right] d_{t+1+i}\right)
$$

If the margin requirement never binds, this expression reduces to a standard asset-pricing formula. In the case that margin calls are possible, the effects on the price of equity are easier to interpret if the definition $E_{t}\left[R_{t+1}^{q}\right] \equiv E_{t}\left[\left(d_{t+1}+q_{t+1}\right) / q_{t}\right]$ is used to re-write (21) as follows:

$$
q_{t}=E_{t}\left(\sum_{i=0}^{\infty}\left[\prod_{j=0}^{i} E_{t}\left[R_{t+1+j}^{q}\right]\right]^{-1} d_{t+1+i}\right)
$$

where the sequence of $E_{t}\left[R^{q}{ }_{t+1+j}\right]$ is given by (20). If margin requirements are binding at present, or expected to bind in the future, some or all of the expected returns on equity used to discount the future stream of dividends in the above formula increase and thus the current price of equity falls. Moreover, the date- $t$ equity price falls whenever the margin requirement is expected to bind in the future, even if it were not binding at date $t$ (i.e., all what is required for $q_{t}$ to fall is that $\eta_{t+j}>0$ for some $j>t$ ).

As in Section 3, the government sets the value of the tax or tariff rate $\tau_{t}$ and uses the 
revenue to finance unproductive expenditures $G_{t}$ maintaining a balanced-budget policy:

$$
G_{t}=\tau_{t} C_{t}
$$

Thus, sudden changes in taxes or tariffs introduce the Calvo-Drazen fiscal-induced wealth effect present in the model with liquidity constraints.

Foreign securities firms maximize the present discounted value of dividends $D$ to their global share-holders, facing a quadratic adjustment cost in adjusting equity positions in the small open economy. These firms choose their equity position $a_{t+1}^{*}$ for $\mathrm{t}=0, \ldots, \infty$ so as to maximize:

$$
D=E_{0}\left[\sum_{t=0}^{\infty} M_{t}\left(a_{t}^{*} K\left(d_{t}+q_{t}\right)-q_{t} a_{t+1}^{*} K-q_{t}\left(\frac{s}{2}\right)\left(\left(a_{t+1}^{*}-a_{t}^{*}\right) K+\theta\right)^{2}\right)\right]
$$

where $M_{0} \equiv 1$ and $M_{t}$ for $t=1, \ldots, \infty$ are the exogenous discount rates that apply to date- $t$ dividends. The parameter $s$ is a "speed-of-adjustment" coefficient and $\theta$ is a long-run cost of holding a timeinvariant equity position in the small open economy. This cost is assumed to be zero if the longrun equity price is to be equal to its "fundamentals" level, as defined below, otherwise the cost is positive and time-invariant.

The first-order condition for the optimization problem of securities firms implies a partial-adjustment rule for their portfolio of the form:

$$
\left(a_{t+1}^{*}-a_{t}^{*}\right) K=s^{-1}\left(\frac{q_{t}^{f}}{q_{t}}-1\right)-\theta
$$

where $q^{f}{ }_{t}$ is the "fundamentals" price of equity defined as:

$$
q_{t}^{f}=E_{t}\left(\sum_{i=1}^{\infty} \frac{M_{t+i}}{M_{t}} d_{t+i}\right)
$$

According to (25), foreign firms increase their demand for equity by a fraction of the percent 
deviation of the date-t equity price below the corresponding fundamentals level. This adjustment in demand is inversely related to the value of $s$. Thus, the informational friction behind the portfolio adjustment cost is key to support equilibrium equity prices below the fundamentals levels. If securities firms could adjust their portfolios at no cost, households could liquidate the shares they need to meet margin calls at an infinitesimal price discount.

If the margin requirement never binds, the small open economy is one of many identical economies conforming the world economy, so the discount rates in (21) and (26) are the same. Thus, if the margin requirement never binds the equilibrium price is the fundamentals price and neither domestic residents or foreign traders alter their equity positions. If the constraint binds, however, $q_{t}^{f}$ remains the same (since the discount rates of foreign traders are exogenous and the stream of dividends is independent of portfolio decisions), but the equilibrium equity price will fall below it depending on how much pressure the margin call puts on domestic residents to fire sell equity relative to how quickly the foreign traders are able to adjust their portfolios.

The effects of exogenous shocks to global capital markets (such as shocks to the world real interest rate) on asset prices and equity flows can be examined using this model in an analogous manner as the "liquidity shocks" examined by Aiyagari and Gertler (1999). The effects of productivity shocks, policy shocks, and shocks to the margin coefficient $\kappa$ can also be studied. These experiments would capture some of the features of the episode of waves of margin calls observed in the aftermath of the Russian default in 1998. During this episode, margin calls were triggered by increasing estimates of potential portfolio losses produced by the value-at-risk models of investment banks that leveraged the operations of hedge funds like Long Term Capital Management. As market volatility increased and asset prices plummeted, value-atrisk estimates worsened thereby mandating even larger margin calls. Similarly, in the model, 
shocks that make equity prices fall below fundamentals trigger an endogenous increase in the level of the margin requirement (even if $\kappa$ remains unchanged). The sharper the decline in equity prices, the larger the size of the margin call.

The model cannot be solved in closed-form analytically so the extent to which it can account for observed equity-price corrections and reversals of portfolio flows during Sudden Stops is left for further research (see Mendoza and Smith (2001). Still, the model's deterministic steady state offers interesting insights on the long-run implications of the margin constraint for asset prices. If the margin constraint is not binding at steady state (and hence the long-run portfolio adjustment cost vanishes), the steady-state equity price equals the fundamentals price:

$\bar{q}=\bar{q}^{f}=\bar{d} /(\bar{R}-1)$. Implicit in this equality is the fact that the return on equity, $(\bar{q}+\bar{d}) / \bar{q}$, equals the gross rate of return on foreign assets (i.e., there is no equity premium).

If the margin requirement is binding at steady state (and hence $\theta>0$ ), the partialadjustment portfolio rule of securities firms implies that the steady-state equity price satisfies: $\bar{q}=\bar{q}^{f} /(1+s \theta)<\bar{q}^{f}$. This price is supported as an equilibrium price from the household's side because the margin requirement and the endogenous rate of time preference result in a long-run equity premium: the steady-state rate of return on equity exceeds the world risk-free rate of return by the amount $\kappa(\eta / \lambda)$. Thus, under the assumed specification of preferences, the financial and informational frictions implied by the margin constraint and the portfolio adjustment cost combine to yield a stationary equilibrium in which equity prices can deviate permanently from their fundamentals value and the margin constraint always binds.

\section{Conclusions and Policy Implications}

This paper provides an account of the Sudden Stops phenomenon of the 1990s emerging- 
markets as an "excess volatility" phenomenon, that is as unusually large recessions that go unnoticed in long-run business cycle co-movements. Sudden Stops occur when borrowing constraints become endogenously binding as a result of shocks to productivity, the world real interest rate or domestic policy variables. This is possible because debt contracts are written in units of tradable goods while part of the debt is leveraged on the income of the nontradables sector. Adverse real or policy shocks induce sharp collapses in the production and/or relative price of nontradables and thus contribute to tighten credit constraints. Sudden Stops and large fluctuations in the real exchange rate occur in this economy even though goods and factor markets are competitive, prices are completely flexible, and the equilibrium is unique. In addition, welfare analysis shows that the social costs of these Sudden Stops can be large.

The findings of this study suggest that policy intervention is worth considering but also that the type of policies that can be effective for managing Sudden Stops need to be carefully chosen. Alternatives considered so far in the literature can be classified as siding with two approaches: an isolationist approach that seeks to avoid Sudden Stops by imposing capital controls and limiting currency trading and an internationalist approach that aims to minimize Sudden Stops by promoting the global integration of domestic financial institutions and by abandoning weak domestic currencies with the adoption of hard currencies (i.e., dollarization). Policies advocated by internationalists counter two important determinants of Sudden Stops identified in this paper: the lack of credibility of economic policies in emerging-markets countries and the perverse combination of heavy-need but weak-incentives for gathering costly information about these countries by global investors and lenders that drives credit-market imperfections (see Calvo and Mendoza (2000b)). Dollarization, for example, does away with the need to keep track of country-specific monetary and exchange rate policies, which have proven 
extremely volatile and hard to predict in periods of capital-markets turbulence. A similar principle applies to fiscal and trade policies that follow regimes with uncertain duration, but which are harder to make credible. Mendoza (2001) finds that the benefits of increased policy credibility in the case of dollarization can be very large. The results of this paper show in addition that the potential gains of structural policies that improve permanently a country's ability to access global capital markets can be substantial.

The analysis of the paper sheds light on some of the drawbacks of policies advocated by isolationists. The dynamic general-equilibrium nature of the model fleshes out the tension between the short-term aim of using capital controls or regulatory practices to target the debtoutput ratio of an economy to prevent a Sudden Stop and the dynamic implications of this policy. For the policy to effectively remove the risk of Sudden Stops, it must ensure that exposure to large capital outflows is fully avoided, but this can only be guaranteed in the long run and if the stock of foreign liabilities is severely restricted. However, the dynamic welfare cost of this policy can be potentially large because the situation can be viewed as a worst-case scenario equivalent to one in which the model's borrowing constraints are very tight. Sudden Stops are avoided, domestic saving is high and long-run private consumption is high, but this is the result of very costly distortions on short-run dynamics. Moreover, for economies starting from a position of high debt, the implementation of policies to target the debt-output ratio increases the short-run probability and magnitude of Sudden Stops.

Policies less drastic than capital controls but with a similar aim of stabilizing capital flows, such as short-selling constraints, margin requirements, and collateral constraints linked to value-at-risk estimates have other negative features. Short-selling constraints exacerbate the loss of incentives to gather costly information, as Calvo and Mendoza (2000b) showed, while margin 
requirements and collateral constraints strengthen the mechanisms driving excess volatility of asset prices and international capital flows examined in this paper.

The model proposed here is only a first approximation to study Sudden Stops as an excess volatility phenomenon within a dynamic general equilibrium framework. Three obvious directions for further research are to study the asset-pricing implications of models similar to the one sketched in Section 5, to introduce capital accumulation and monetary transmission mechanisms, and to endogenize the microfoundations of the credit frictions within the macroeconomic model. 


\section{References}

Agenor, Pierre-Richard, C. John McDermott, and Eswar S. Prasad, (2000), "Macroeconomic Fluctuations in Developing Countries: Some Stylized Facts," World Bank Economic Review, forthcoming.

Aizenman, Joshua, and Nancy Marion, (1993) "Policy Uncertainty, Persistence and Growth," Review of International Economics, June, 145-163.

Aghion, Philippe, Philippe Bacchetta, and Abhijit Banerjee, (2000), “Currency Crises and Monetary Policy with Credit Constraints," mimeo, Department of Economics, Harvard University.

Aiyagari, S. Rao (1993), "Explaining Financial Market Facts: The Importance of Incomplete

Markets and Transaction Costs." Federal Reserve Bank of Minneapolis Quarterly Review 17, 1731. and Mark Gertler, (1999), “' 'Overreaction’ of Asset Prices in General Equilibrium,”

Review of Economic Dynamics.

Bernanke, Ben, Gertler, Mark and Simon Girlchrist, (1998), “The Financial Accelerator in a Quantitative Business Cycle Framework.” NBER Working Paper No. 6455, National Bureau of Economic Research, Cambridge: MA.

Caballero, Ricardo J. and Arvind Krishnamurthy, (1999), "Emerging Markets Crises: An Asset Markets Perspective.” Mimeo, Sloan School of Business, MIT, Cambridge: MA.

Calvo, Guillermo A., (1986), "Temporary Stabilization: Predetermined Exchange Rates."

Journal of Political Economy 94, pp.1319-1329. (1998), “Capital Flows and Capital-Market Crises: The Simple Economics of Sudden

Stops," Journal of Applied Economics, v. 1, pp. 35-54 
$-51-$ , and Allan Drazen, (1998), “Uncertain Duration of Reform: Dynamic Implications,"

Macroeconomic Dynamics. , and Carmen M. Reinhart (1999), "When Capital Inflows come to a Sudden Stop:

Consequences and Policy Options," mimeo, Center for International Economics, Department of Economics, University of Maryland. , and Enrique G. Mendoza (2000a), "Capital-Markets Crises and Economic Collapse in Emerging Markets: An Informational-Frictions Approach,” American Economic Review: Papers and Proceedings, May. , and Enrique G. Mendoza (2000b), "Rational Contagion and the Globalization of

Securities Markets," Journal of International Economics, v. 51.

Carroll, Christopher D., (2000), “A Theory of the Consumption Function, With and Without Liquidity Constraints,” mimeo, Department of Economics, Johns Hopkins University.

Cespedes, Luis, Roberto Chang and Andres Velasco, (2000) "Balance Sheets and Exchange Rate Policy." Mimeo, Department of Economics, New York University.

Christiano, Lawrence J., Christopher Gust and Jorge Roldos, (2000), "Monetary Policy in an International Financial Crisis." Mimeo, Research Department, International Monetary Fund, Washington DC.

Cole, Harold L. and Maurice Obstfeld, (1991), “Commodity Trade and International Risk Sharing: How Much do Financial Markets Matter?," Journal of Monetary Economics, August. Dornbusch, Rudiger and Alejandro Werner, (1994), "Mexico: Stabilization, Reform and No Growth," Brookings Papers on Economic Activity, 1:1994, pp. 253-316.

Eaton, Jonathan, and Mark Gersovitz (1981), “Debt with Potential Repudiation: Theoretical and Empirical Analysis," Review of Economic Studies, v. XLVIII, 289-309. 
Edwards, Sebastian, (2000), "Do Current Account Imbalances Matter?," mimeo, Department of Economics, University of California-Los Angeles. (1986), “Are Devaluations Contractionary?”, Review of Economics and Statistics,v. 68, pp. 501-508.

Epstein, Larry G. (1983) "Stationary Cardinal Utility and Optimal Growth under Uncertainty", Journal of Economic Theory, 31, 133-152.

Fisher, Irving, (1933), “The Debt-Deflation Theory of Great Depressions,” Econometrica 1, 33757.

Forbes, Kristin and Roberto Rigobon (1999), “No Contagion, Only Interdependence: Measuring Stock Market Co-Movements," NBER Working Paper No. 7267.

Frankel, Jeffrey A. and Schmukler, Sergio (1996), "Country Fund Discounts and the Mexican Crisis of December 1994," Open Economies Review, Suppl. 1, 7, 551-84

Greenwood, Jeremy, Zvi Hercowitz and Gregory W. Huffman (1988) "Investment, Capacity Utilization and the Real Business Cycle", American Economic Review, June.

Guerra de Luna, Alfonso, (1997), “La Relevancia Macroeconómica de los Bienes Raíces en México," Serie Documentos de Investigación, Documento No. 9707, Dirección General de Investigación Económica, Banco de México, Mexico City: Mexico. (1998), “Capital Inflows and Mortgage Crisis: The Case of Mexico," mimeo,

Economic Studies Division, Banco de México, Mexico City: Mexico.

International Monetary Fund, (1999), International Capital Markets, September, International Monetary Fund, Washington: DC.

Kaminsky, Graciela L. and Carmen M. Reinhart, (2000), “On Crises, Contagion, and Confusion," Journal of International Economics, v. 51, pp.145-168. 
Kiyotaki, Nobuhiro and John Moore, (1997), “Credit Cycles," Journal of Political Economy, v. $105,211-248$.

Lane, Philip and Gian Maria Milesi-Ferretti (1999), “The External Wealth of Nations: Measures of Foreign Assets and Liabilities for Industrial and Developing Countries," IMF Working Paper No. WP/99/115, International Monetary Fund, Washington DC.

Lucas, Robert E., Jr. (1987), Models of Business Cycles, Basil-Blackwell, New York: NY. Ludvigson, Syndey, (1996), “Consumption and Credit: A Model of Time-Varying Liquidity Constraints," Ph.D. Dissertation, Department of Economics, Princeton University. Mendoza, Enrique G. (2001), “The Benefits of Dollarization when Stabilization Policy Lacks Credibility and Financial Markets are Imperfect," Journal of Money, Credit and Banking, forthcoming. ,and Martin Uribe (2001), "Devaluation Risk and the Business Cycle Implications of

Exchange Rate Management," Carnegie-Rochester Conference Series on Public Policy, vol. 53, forthcoming.

and Katherine A. Smith, (2001), "Margin Calls, Trading Costs and the Sudden Stops of Capital Inflows into Emerging Markets," mimeo, Department of Economics, Duke University. (1995), "The Terms of Trade, The Real Exchange Rate and Economic Fluctuations,"

International Economic Review, v. 36, 101-137, February. (1997), “Terms-of-Trade Uncertainty and Economic Growth,” Journal of Development Economics, v. 54, pp. 323-356, (1991a), "Real Business Cycles in a Small Open Economy," American Economic Review, v. 81, 797-818, September. (1991b), "Capital Controls and the Gains from Trade in a Business Cycle Model of a 
Small Open Economy," IMF Staff Papers, September, v. 38, 480-505.

Ostry, Jonathan D. and Carmen M. Reinhart (1992), "Private Saving and Terms of Trade Shocks," IMF Staff Papers, 39, 495-517.

Paasche, Bernhard, (2001), “Credit Constraints and International Financial Crises, "Journal of Monetary Economics, forthcoming.

Ramey, Garey and Valerie A. Ramey, (1995) "Cross-Country Evidence on the Link between Volatility and Growth," American Economic Review, v. 85, pp. 1138-1151.

Schneider, Martin and Aaron Tornell, (2000), "Balance Sheet Effects, Bailout Guarantees and Financial Crises,” NBER Working Paper No. W8060, National Bureau of Economic Research. 


\section{Appendix I}

Given the assumptions made in Section 3 about the lifetime utility function and its components $u, v, C$ and $H$, it is easy, though lengthy, to show that the first-order conditions for the households' optimization problem can be simplified to the following expressions:

$$
\begin{gathered}
U_{C}(t)\left(1-\frac{\mu_{t}}{\lambda_{t}}\right)=\exp (-v(t)) E_{t}\left[\frac{R p_{t}^{C}\left(1+\tau_{t}^{C}\right)}{p_{t+1}^{C}\left(1+\tau_{t+1}^{C}\right)} U_{C}(t+1)\right] \\
\frac{C_{C^{N}}(t)\left(1+\tau_{t}^{T}\right)}{C_{C^{T}}(t)\left(1+\tau_{t}^{N}\right)}=p_{t}^{N} \\
H^{\prime}\left(L_{t}\right)=\left(\frac{w_{t}}{p_{t}^{C}\left(1+\tau_{t}^{N}\right)}\right)\left[1+\frac{\mu_{t}}{\lambda_{t}} \frac{1-\varphi}{\varphi}\right]
\end{gathered}
$$

$\mu$ and $\lambda$ are the nonnegative multipliers on the liquidity constraint and the budget constraint respectively. The terms in $U_{C}$ are derivatives of lifetime utility with respect to $C$. These include "impatience effects" by which changes in consumption or labor supply at any date $t$ alter the rate at which all period utilities after $t$ are discounted.

\section{Appendix II}

The competitive equilibrium of the small open economy described in Section 3 can be characterized as the solution to the following social planner's problem The state variables of the system at any date $t$ include: $b \equiv b_{t}$ and the observed realizations of the exogenous shocks $\psi \equiv$ $\left(\varepsilon_{t}^{T}, \varepsilon_{t}^{N}, \varepsilon_{t}{ }^{R}, \tau_{t}\right)$. Conditional on these state variables and the Markov processes driving the shocks, the planner chooses an optimal value for $b^{\prime} \equiv b_{t+1}$ so as to solve the following Bellman equation: 


$$
V(b, \psi)=\max \left\{u(\hat{C}-H(\hat{L}))+\exp (-v(\hat{C}-H(\hat{L}))) E\left[V\left(b^{\prime}, \psi^{\prime}\right)\right]\right\}
$$

subject to:

$$
\begin{gathered}
(1+\tau) \hat{C}^{T}+\tau \hat{p}^{N} \hat{C}^{N}=\exp \left(\varepsilon^{T}\right) Y^{T}-b^{\prime}+b \exp \left(\varepsilon^{R}\right) R-T^{T} \\
\hat{C}^{N}=\exp \left(\varepsilon^{N}\right) F(K, \hat{L})-G^{N} \\
b^{\prime} \geq-\left(\frac{1-\varphi}{\varphi}\right)\left(\exp \left(\varepsilon^{T}\right) Y^{T}+\hat{p}^{N} \exp \left(\varepsilon^{N}\right) F(K, \hat{L})\right)
\end{gathered}
$$

The variables in "hats" represent solutions of a system of four nonlinear simultaneous equations in four unknowns for each coordinate $\left(b, b^{\prime}, \psi\right)$ in the state space. If the liquidity constraint (A2.4) is not binding, the system includes the equilibrium conditions equating the marginal rate of substitution of $C^{T}$ and $C^{N}$ with $p^{N}$ (equation (A1.2)) and the marginal rate of substitution between labor and $C^{T}$ with the effective real wage (equation (A1.3)), and the marketclearing conditions (A2.2) and (A2.3). If the liquidity constraint is binding, (A2.4) holds with equality and replaces the labor-consumption optimality condition (A1.3). The solutions to this system are not the equilibrium of the model, they represent allocations of the "hat" variables that satisfy a subset of the equilibrium conditions given any arbitrary set $\left(b, b^{\prime}, \psi\right)$ in the state space.

The above dynamic programming problem is solved by iterations on the Bellman equation in a "discrete" state space. This method captures accurately the nonlinearities induced by the liquidity constraint, although it is slow and memory intensive. 
Table 1. Stylized Facts of Mexican Business Cycles

\begin{tabular}{|c|c|c|c|c|c|c|c|c|}
\hline & \multirow[b]{2}{*}{ Minimum } & \multirow{2}{*}{$\begin{array}{l}\text { Standard } \\
\text { Deviation }\end{array}$} & \multicolumn{2}{|c|}{ Ratios relative to Nontradables GDP } & \multirow{2}{*}{$\begin{array}{c}\text { First-order } \\
\text { Autocorrelation }\end{array}$} & \multicolumn{3}{|c|}{ Correlation with: } \\
\hline & & & Minimum & Standard Dev. & & GDP & Tradables GDP & Nontradables GDP \\
\hline GDP & -7.936 & 2.734 & 1.196 & 0.997 & 0.647 & 1.000 & 0.885 & 0.946 \\
\hline Tradables GDP & -10.145 & 3.368 & 1.529 & 1.229 & 0.553 & 0.885 & 1.000 & 0.685 \\
\hline Nontradables GDP & -6.633 & 2.741 & 1.000 & 1.000 & 0.657 & 0.946 & 0.685 & 1.000 \\
\hline Price of nontradables & -24.409 & 8.088 & 3.680 & 2.951 & 0.899 & 0.626 & 0.534 & 0.607 \\
\hline Consumption & -8.567 & 3.347 & 1.292 & 1.221 & 0.664 & 0.922 & 0.853 & 0.846 \\
\hline Government Expenditures & -9.126 & 4.544 & 1.376 & 1.658 & -0.076 & 0.419 & 0.442 & 0.344 \\
\hline Investment & -28.007 & 11.083 & 4.222 & 4.043 & 0.783 & 0.892 & 0.834 & 0.815 \\
\hline Net Exports & -48.193 & 19.216 & 7.265 & 7.010 & 0.794 & -0.608 & -0.713 & -0.456 \\
\hline World real interest rate & -1.458 & 0.881 & 0.220 & 0.321 & 0.771 & -0.235 & -0.116 & -0.279 \\
\hline
\end{tabular}

Note: These statistics were computed using quarterly seasonally-adjusted data for the period 1980:1-1997:4, except for the real interest rate which is for the period 1983:1-1996:3.

The data were logged and detrended using the Hodrick-Prescott filter with the smoothing parameter set at 1600. The real interest rate is the London quote of the Eurodollar nominal interest rate minus the consumer price inflation of industrial countries, both reported in the IMF's International Financial Statistics as series $60 \mathrm{~d}$, code 112 and series 64 , code 110 respectively. This is the same measure of the real interest rate proposed by Agenor, McDermott and Prasad (2000). Net exports are defined as detrended exports minus detrended imports. "Minimum" corresponds to the smallest deviations from the Hodrick-Prescott trends, which are all dated 1995:2 (except for the world real interest rate). 
Table 2. Parameter Values for the Calibrated Deterministic Stationary State

\begin{tabular}{|c|c|c|c|c|c|}
\hline Technology: & & Fiscal policy: & & Credit market: & \\
\hline$\alpha$ & 0.364 & $T$ & 0.079 & $R$ & 1.016 \\
\hline$A$ & 1.958 & $T$ traded & -0.139 & $\varphi$ & 0.740 \\
\hline$Y T$ & 1.000 & T nontraded & 0.119 & $b / Y$ & -0.350 \\
\hline Preferences: & & National accou & & & \\
\hline$\beta$ & 0.027 & $C / Y$ & 0.684 & $C T / Y T$ & 0.665 \\
\hline$\delta$ & 2.000 & $I / Y$ & 0.217 & $G T / Y T$ & 0.017 \\
\hline$\eta$ & 0.316 & $G / Y$ & 0.092 & $I T / Y T$ & 0.323 \\
\hline$\omega$ & 0.342 & $N X / Y$ & -0.001 & $C N / Y N$ & 0.708 \\
\hline \multirow[t]{2}{*}{$\sigma$} & 2.000 & $Y T / Y N$ & 0.648 & $G N / Y N$ & 0.141 \\
\hline & & & & $I N / Y N$ & 0.151 \\
\hline
\end{tabular}


Table 3. Business Cycle Comovements in the Limiting Distribution of Model Economies

\begin{tabular}{|c|c|c|c|c|c|}
\hline & Mean & $\begin{array}{l}\text { Standard } \\
\text { Deviation }\end{array}$ & $\begin{array}{l}\text { Standard Dev. } \\
\text { relative to GDP of } \\
\text { nontradables }\end{array}$ & $\begin{array}{c}\text { First-order } \\
\text { Autocorrelation }\end{array}$ & $\frac{\text { Correlation with }}{\text { GDP }}$ \\
\hline \multicolumn{6}{|c|}{ Economy with Perfect Credit Markets } \\
\hline Net foreign assets & -0.097 & 0.883 & 14.274 & 0.999 & 0.321 \\
\hline GDP in units of tradables & 2.598 & 7.307 & 1.829 & 0.931 & 1.000 \\
\hline Tradables GDP & 1.000 & 3.368 & 0.843 & 0.553 & 0.387 \\
\hline Nontradables GDP & 1.548 & 3.995 & 1.000 & 0.633 & 0.387 \\
\hline Labor & 0.524 & 5.003 & 1.252 & 0.928 & 0.976 \\
\hline Consumption & 0.924 & 6.254 & 1.565 & 0.839 & 0.823 \\
\hline Consumption of tradables & 0.683 & 10.162 & 2.544 & 0.934 & 0.996 \\
\hline Consumption of nontradables & 1.097 & 5.635 & 1.411 & 0.633 & 0.387 \\
\hline Net Exports & 0.002 & 25.987 & 6.504 & 0.623 & -0.025 \\
\hline Price of nontradables & 1.033 & 11.925 & 2.985 & 0.815 & 0.874 \\
\hline World real interest rate & 1.016 & 0.880 & 0.220 & 0.553 & -0.071 \\
\hline \multicolumn{6}{|c|}{ Economy with Liquidity Constraint } \\
\hline Net foreign assets & 0.258 & 0.679 & 10.957 & 0.999 & 0.313 \\
\hline GDP in units of tradables & 2.612 & 7.323 & 1.830 & 0.931 & 1.000 \\
\hline Tradables GDP & 1.000 & 3.368 & 0.842 & 0.553 & 0.391 \\
\hline Nontradables GDP & 1.549 & 4.002 & 1.000 & 0.633 & 0.391 \\
\hline Labor & 0.525 & 5.008 & 1.252 & 0.928 & 0.978 \\
\hline Consumption & 0.927 & 6.266 & 1.566 & 0.838 & 0.823 \\
\hline Consumption of tradables & 0.688 & 10.158 & 2.538 & 0.934 & 0.996 \\
\hline Consumption of nontradables & 1.098 & 5.643 & 1.410 & 0.633 & 0.391 \\
\hline Net Exports & -0.004 & 9.150 & 2.287 & 0.599 & -0.003 \\
\hline Price of nontradables & 1.041 & 11.880 & 2.969 & 0.815 & 0.874 \\
\hline World real interest rate & 1.016 & 0.880 & 0.220 & 0.553 & -0.069 \\
\hline
\end{tabular}

Note: All standard deviations are in percent of the corresponding mean, except for the one corresponding to the net foreign asset position. 
Figure 1. Mexico's Sudden Stop

(percent changes with respect to the same quarter of the previous year)
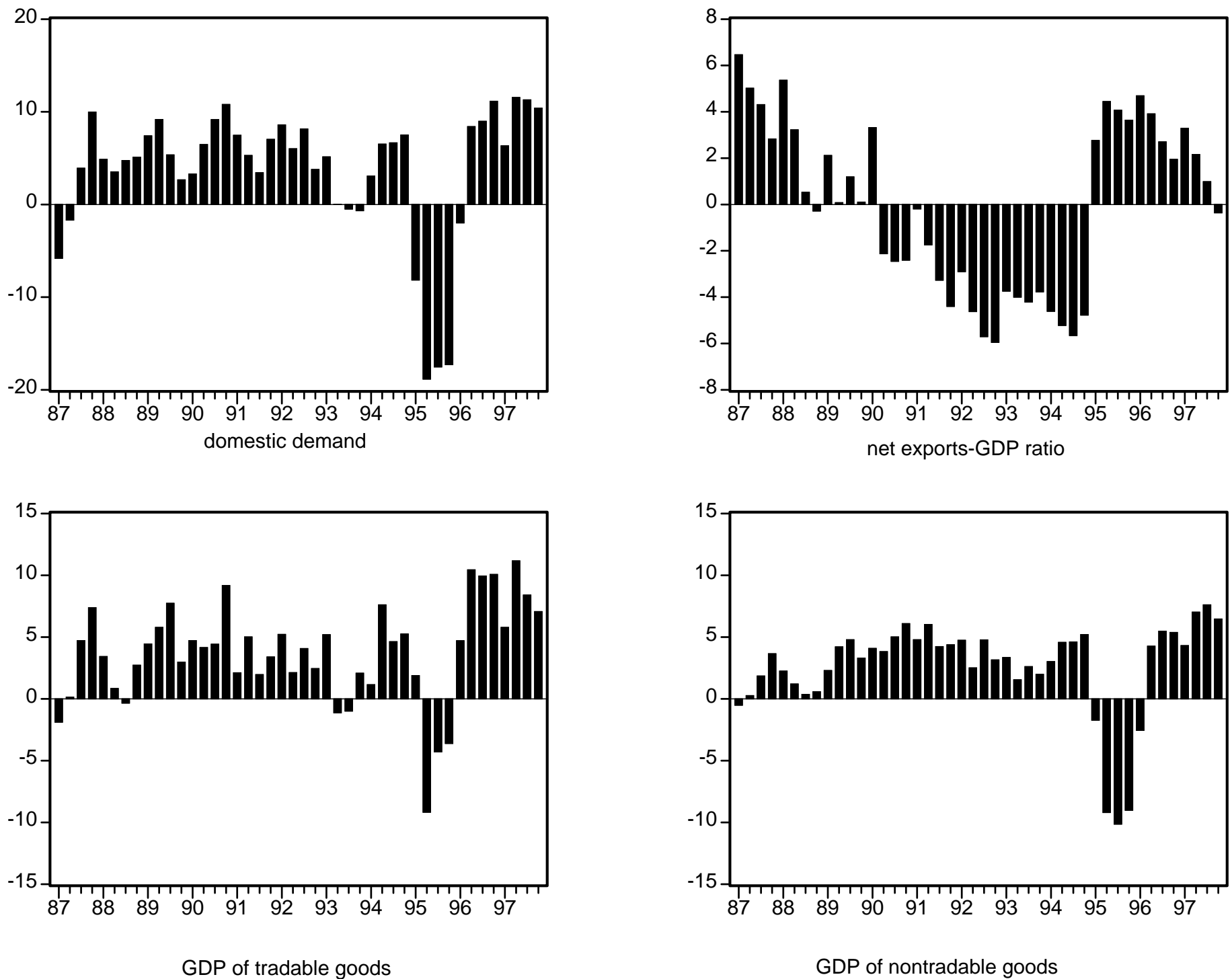
Figure 2. Mexico: Exchange Rates and Relative Prices (indexes based 1988:02=100)

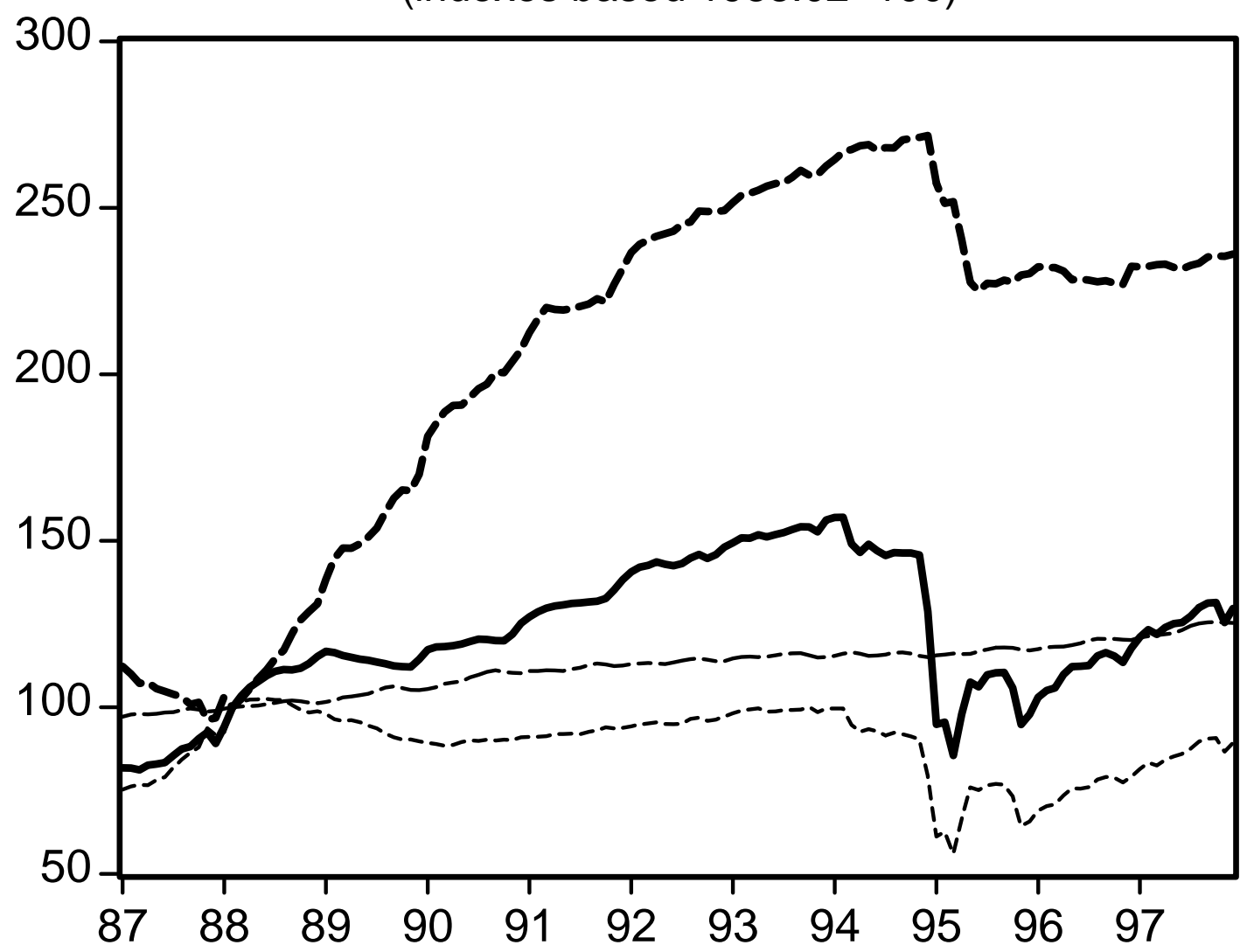

- real exchange rate (CPI based) - - Mexico's nontradables prices nom. ex. rate \& tradables prices ---. US nontradables prices 
Figure 3a. Deviations from Trend in Output and Demand
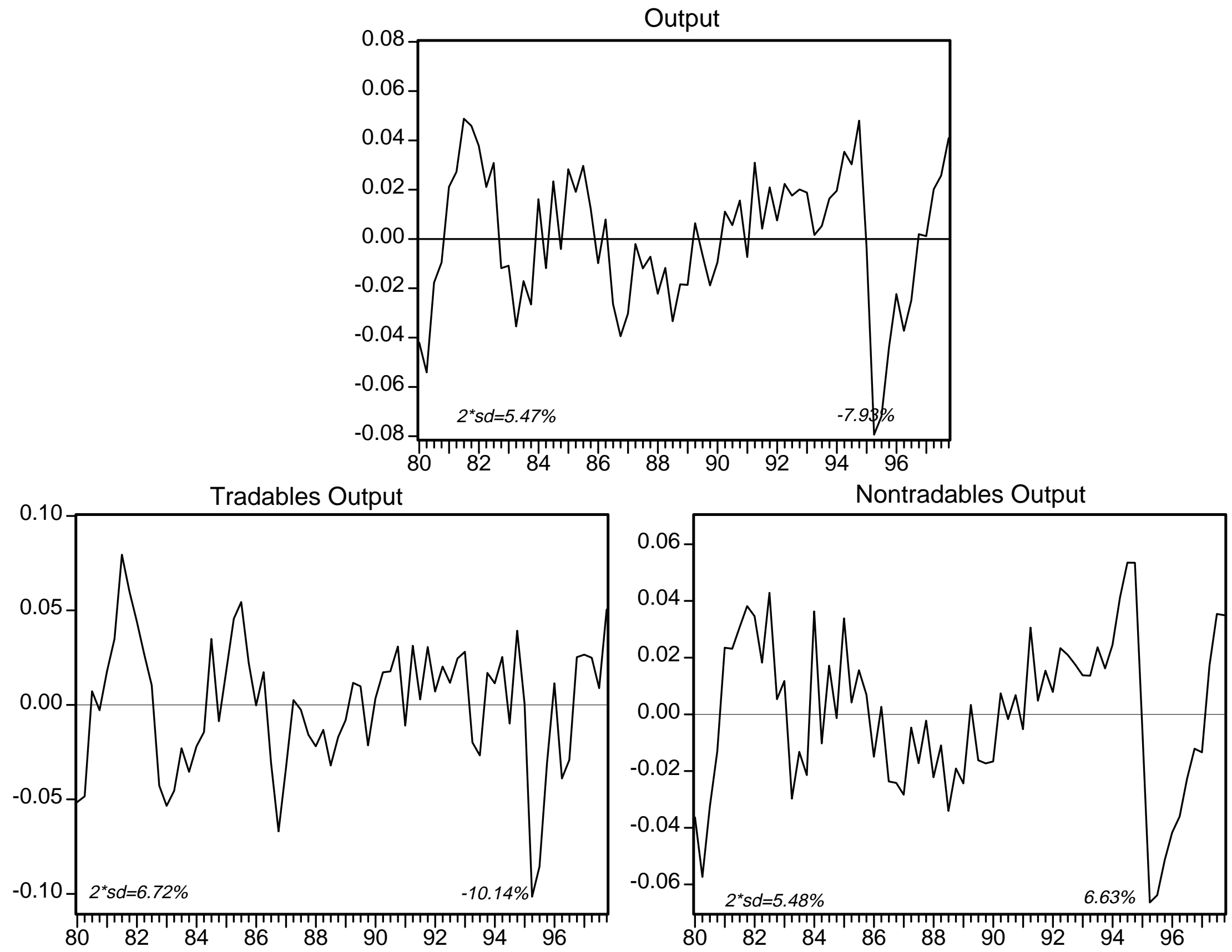
Flgure 3.b. Deviations from Trend in Output and Demand
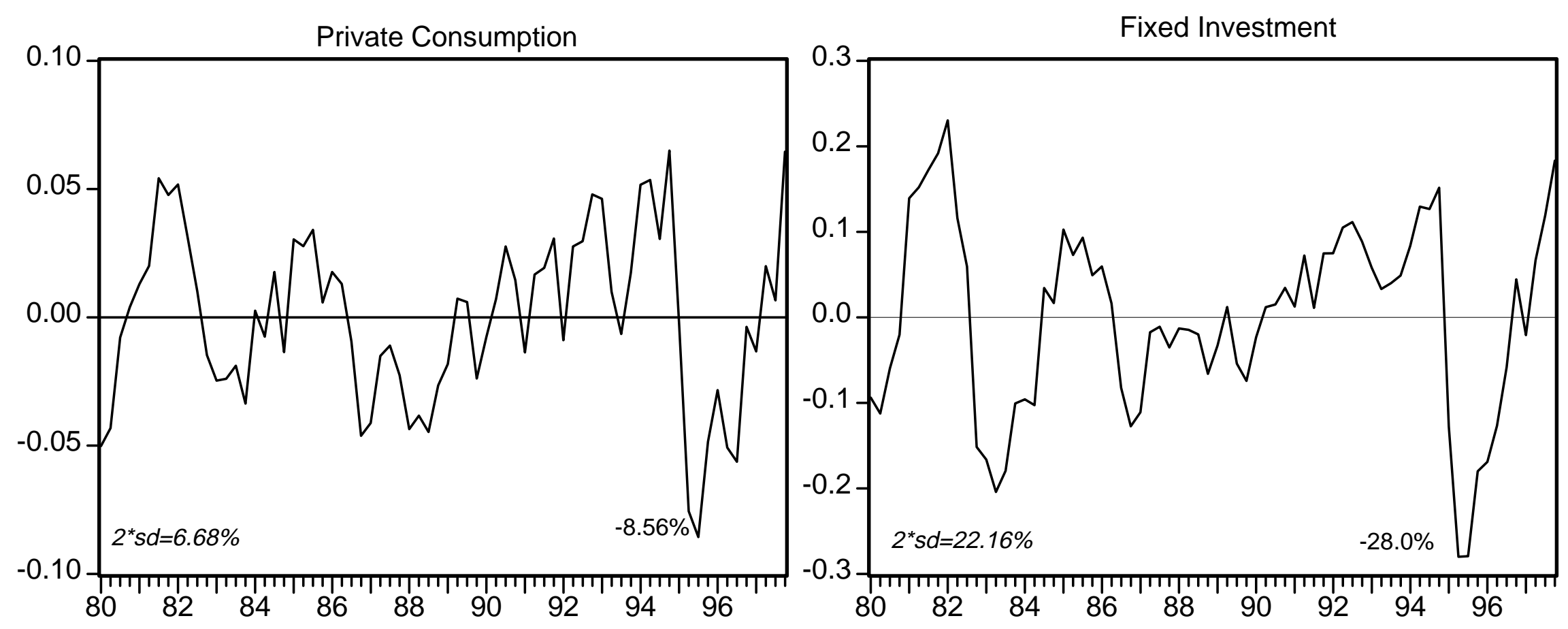
Figure 4. Limiting Distributions of Net Foreign Assets

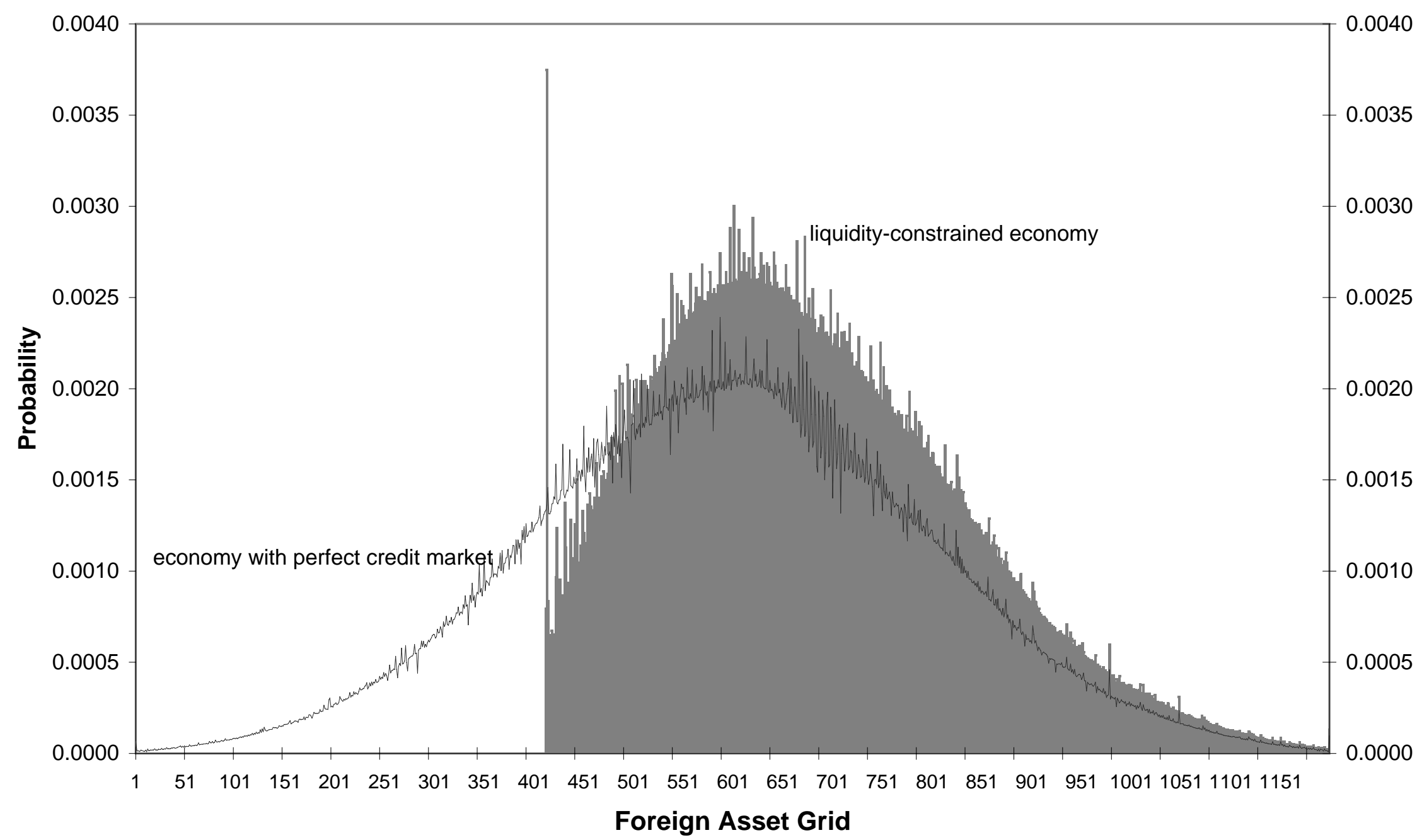


Figure 5. Impact Effects of a Shift from "Best" to "'Worst" State
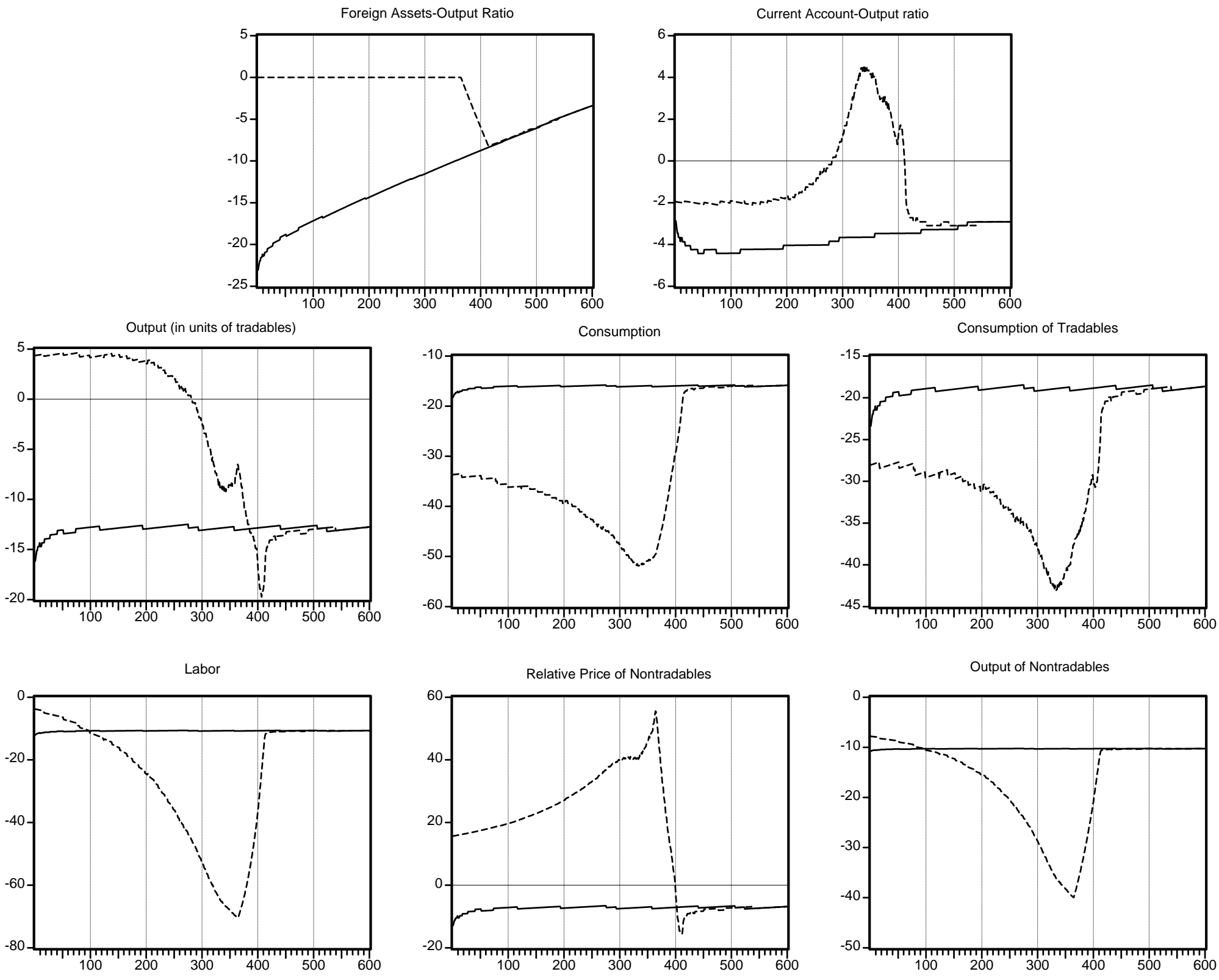

- economy w. perfect credit market --- liquidity constrained economy 
Figure 6. Transition Distributions of Net Foreign Assets in Liquidity Constrained Economy

(from largest initial debt position and random shocks in state 1)

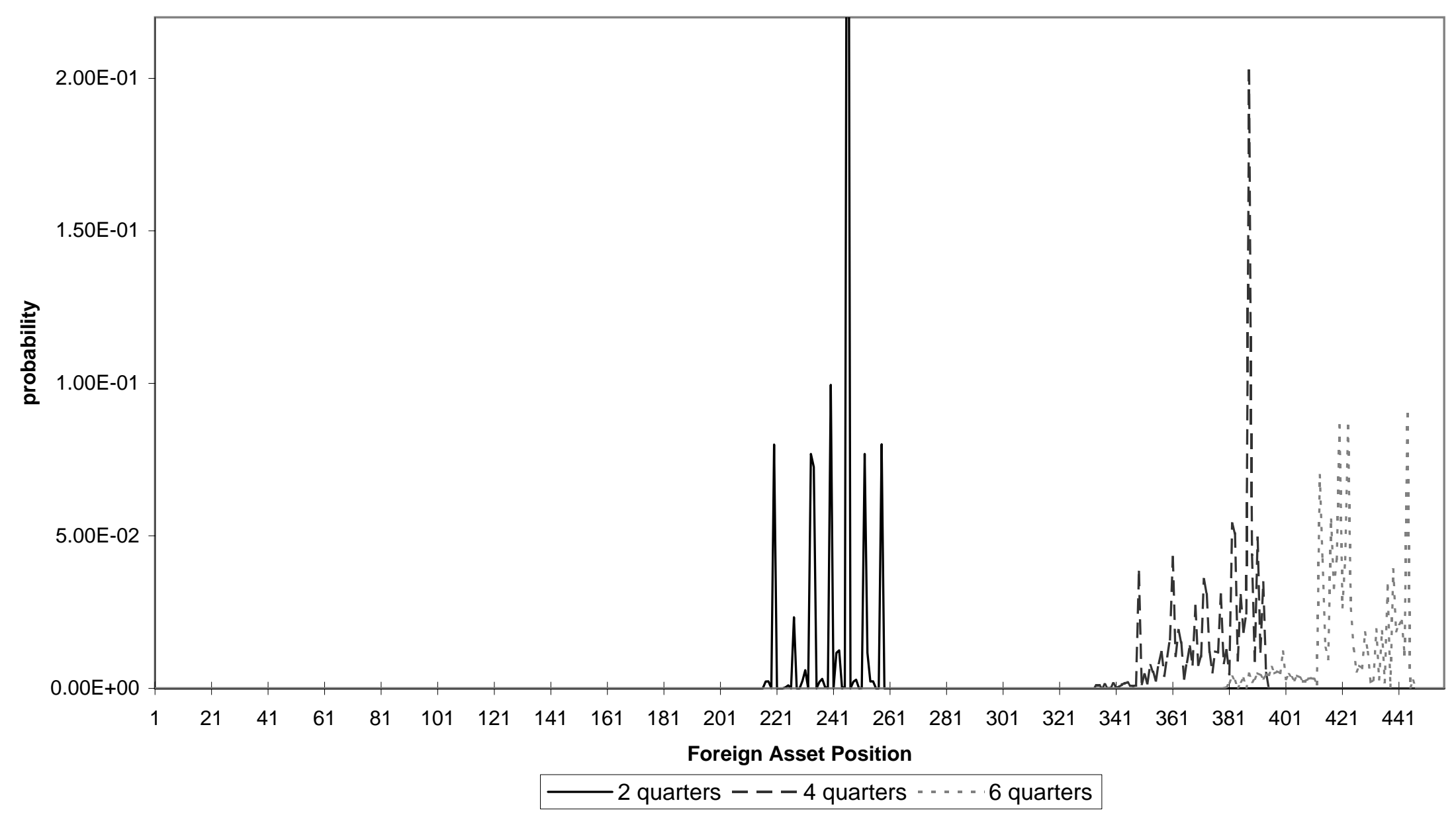


Figure 7. State-Contingent Welfare Losses Induced by Liquidity Constraints

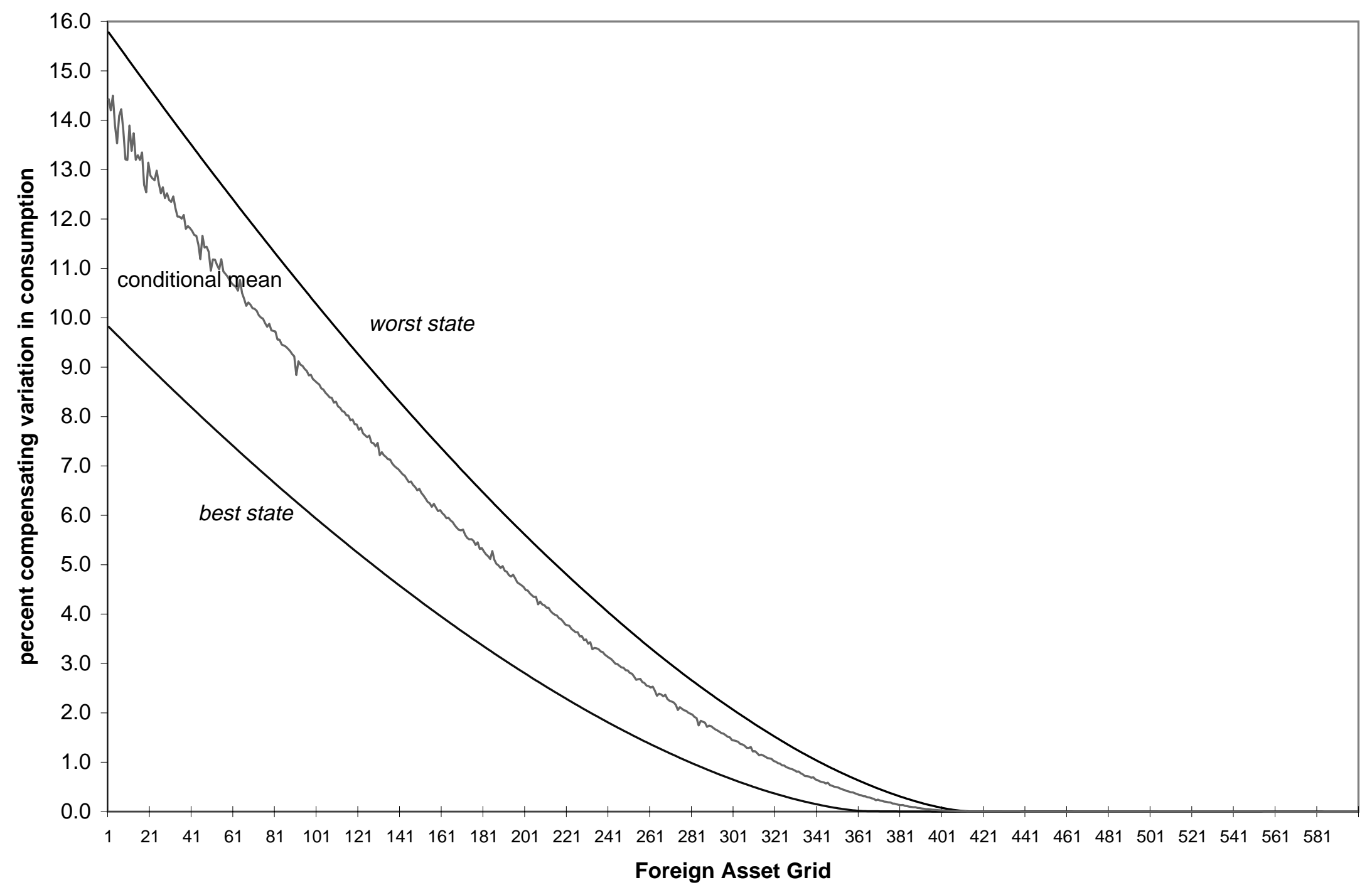


Figure 8

Welfare Cost of Business Cycles

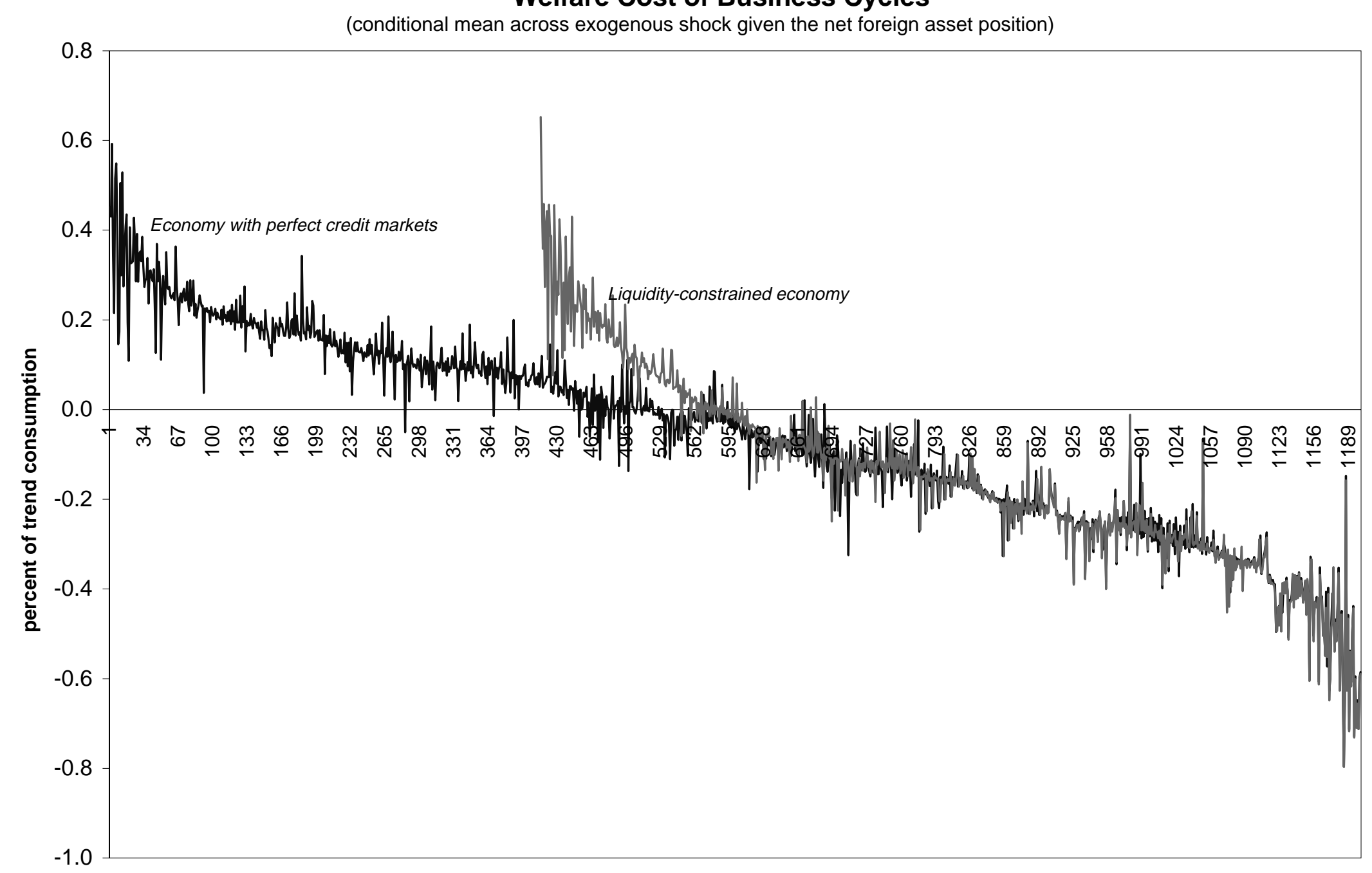

Foreign Asset Grid 
Figure 9. Transition Distributions of Net Foreign Assets in Liquidity Constrained Economy with Risk Aversion Coefficient set at 5 .

(from largest initial debt position and random shocks in state 1)

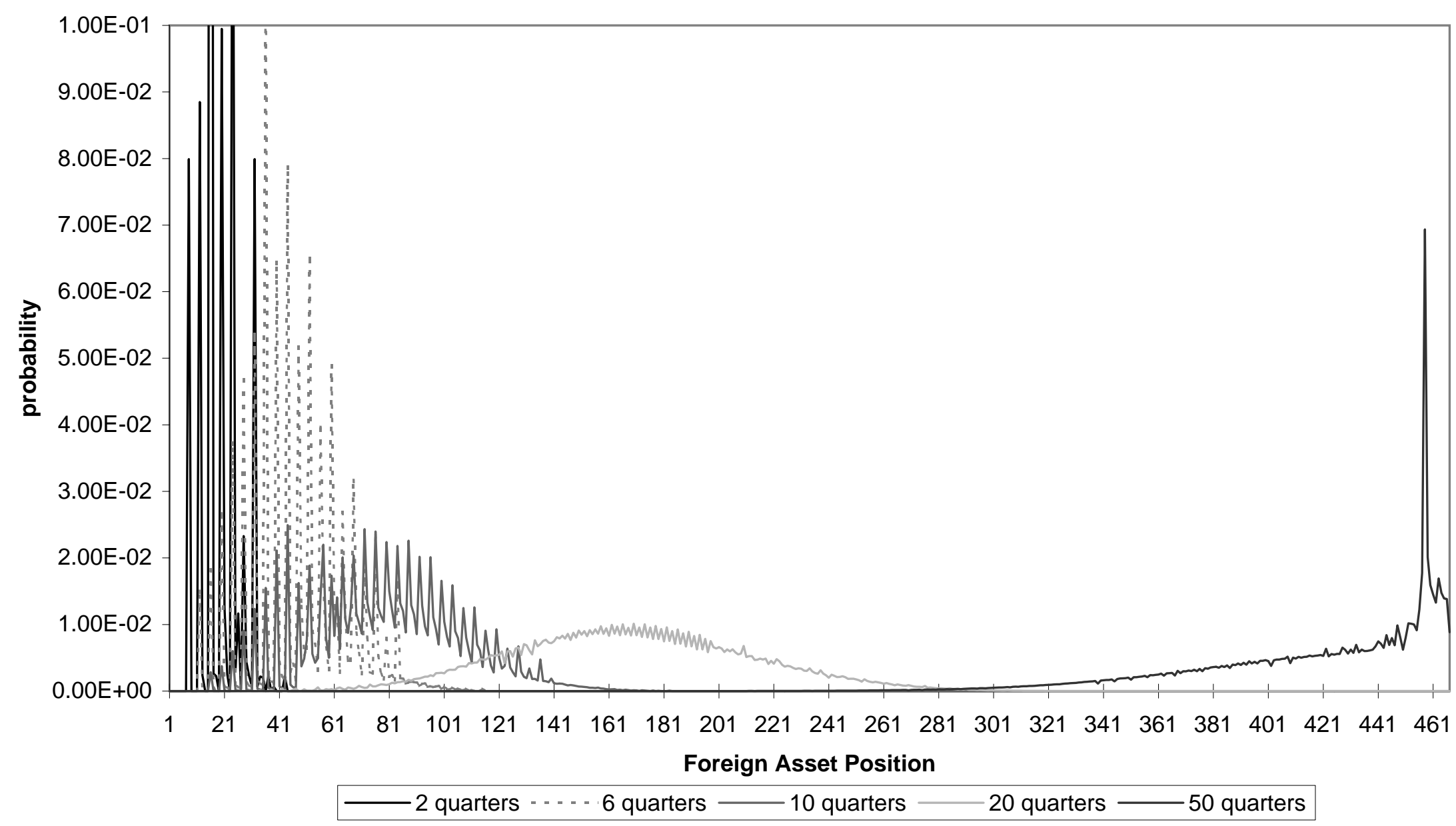

